\title{
Global and local factors driving the phenology of Alexandrium minutum (Halim) blooms and its toxicity
}

\author{
Guallar Carles ${ }^{1,{ }^{*}}$, Bacher Cedric ${ }^{2}$, Chapelle Annie ${ }^{1}$ \\ ${ }^{1}$ IFREMER, DYNECO/PELAGOS, BP 70, 29280 Plouzané, France \\ 2 IFREMER, DYNECO, BP 70, 29280 Plouzané, France \\ * Corresponding author : Carles Guallar, email address : carlesguallar@gmail.com \\ Cedric.Bacher@ifremer.fr ; Annie.Chapelle@ifremer.fr
}

\begin{abstract}
:
The dinoflagellate Alexandrium minutum is a toxic bloom-forming species distributed worldwide. The mechanisms driving and promoting the species blooms and their toxicity are studied and presented here. Most previously published work focuses on local and/or short-term scales. In this study, a broad temporal and spatial approach is addressed using time series covering several sites over several years and combining environmental variables and $A$. minutum abundances from the French English Channel - Atlantic coasts. Data were explored by means of phenology and threshold analysis.
\end{abstract}

The A. minutum bloom characteristics are defined. Only one bloom per year is measured and it may reach more than a million of cells $L-1$. Bloom period extends from April to October and the bloom length ranges from two weeks to six months. In the ecosystems studied, water temperature and river flow, as regional and local factors respectively, are the main environmental drivers influencing the magnitude, growth rate and length of the blooms. Bloom toxicity is linked to the bloom maximum abundance and river flow. This work provides new knowledge for further managing tools for $A$. minutum blooms in the ecosystems studied.

\section{Highlights}

- The Alexandrium minutum blooms and their toxicity were studied. 25 year long time-series from French English Channel-Atlantic coasts were used. Bloom phenology and threshold analysis have been performed. Temperature and river flow are the main bloom shape drivers. Bloom toxicity is linked to bloom maximum abundance and the river flow.

Keywords: Alexandrium minutum, PSP toxicity, HAB, Bloom phenology, Threshold analysis, Monitoring long time-series 


\section{Introduction}

Harmful Algal Blooms (HABs) are phytoplankton proliferations responsible for negative ecological, public health and economical repercussions in aquatic ecosystems all over the world (Hallegraeff, 2003). Among them are toxic microalgae, which produce toxins (Hallegraeff, 2003). One of the major significant toxic species in coastal and estuarine ecosystems is the globally distributed Alexandrium minutum (Anderson et al., 2012). The main threat of this species is its ability to produce Paralytic Shellfish Poisoning (PSP) toxins, contaminating shellfish resources and causing illness and even death in human consumers (Anderson et al., 2012).

Many studies have been carried out to understand A. minutum dynamics and the conditions promoting its toxicity. Laboratory experiments generally focused on a few factors affecting growth, toxin production or determining life-cycle transitions (Chang and McClean, 1997; Figueroa et al., 2007, 2011; Grzebyk et al., 2003; Laabir et al., 2011, 2013; Lim et al., 2006), but these factors usually do not cover the range of environmental conditions. In many field studies dealing with the dynamics and toxicity of this species, only local and/or short-term scales were considered and the findings were therefore constrained by the boundaries of the temporal window and the ecosystem studied (Abdenadher et al., 2012; Bravo et al., 2010; Calbet et al., 2003; Pitcher et al., 2007; Vila et al., 2005; among others). Monitoring programmes give the opportunity to conduct studies on long time-space scales as they provide continuity through time and broad spatial coverage, as well as information on the onset, termination, intensity and toxicity of outbreaks (Wells et al., 2015). The French programme for phytoplankton and phycotoxin monitoring (REPHY), managed by Ifremer, has been recording occurrences of toxic and non-toxic species and also environmental variables (inter alia salinity, temperature, turbidity) since 1984. Several studies highlight the valuable information gathered, including phytoplankton community shifts (Hernández-Fariñas 
et al., 2014) or species niche characterization (Hernández-Fariñas et al., 2015; Husson et al., 2016).

The first A. minutum bloom detected in the French English Channel - Atlantic coasts was in the Bay of Vilaine in 1987 (Lassus and Bardouil, 1988) and since then regularly proliferated causing PSP shellfish closure. Therefore, more than 25 years of data on A. minutum in this area allow an approach on a scale never studied before.

Phytoplankton blooms present recurrent cycles and show variations in the timing and amplitude from year to year and zone, resulting from the integrated interplay of physical and biological processes (Ferreira et al., 2014). Therefore, large temporal and spatial studies of these events can provide great insight into the mechanisms driving them. Phenology is a valuable tool to detect these changes. Many examples exist with terrestrial and limnological species (Parmesan and Yohe, 2003; Walther et al., 2002), and recently, studies in marine science have linked species cardinal dates to climate change (Edwards and Richardson, 2004; Greve et al., 2005; Ji et al., 2010; among others). In the present study, the methodology developed by Rolinski et al. (2007) was chosen to study the A. minutum blooms, as it is adapted to the data set features. Several phenological parameters were determined and related to environmental variables, including PSP toxicity.

This approach aims to identify the global factors modulating the bloom shape. Since the effect of some variables may be masked by the local characteristics of each region studied, a threshold analysis was performed to complement phenology and to bring out the local characteristics of the regions included in the study. It is similar to a niche analysis in which the effect of the environmental variables constraining or triggering A. minutum blooms is studied using the abundance data. This analysis was carried out at local and global scale to better understand the variable effect on the species dynamics. This information is then used to determine the environmental condition modulating each bloom. 
The objectives of this study are to (i) characterise the blooms of A. minutum through the phenology analysis and relate their variability to environmental conditions, and to (ii) study the effect of the environmental conditions triggering or limiting this species abundance and its blooms.

\section{Material and methods}

\subsection{Primary data set}

Data were collected from different sources. The main source was the REPHY monitoring programme, implemented and managed by IFREMER. It includes stations scattered all over the French coastline. Other sources include data from research projects carried out at Ifremer and at the Station Biologique Roscoff (CNRS) from the same area.

Stations and sampling frequencies changed over time as a response to different requirements of the monitoring programme. Three sampling strategies were implemented: Flortot, carried out in few stations with monthly frequency, where all the phytoplankton species $>20 \mu \mathrm{m}$ are enumerated; Florind, to control exceptional phytoplankton blooms (abundances $>10^{5}$ cells L ${ }^{1}$ ) or the presence of toxic species with sanitary purposes; and Florpar, to monitor toxic species with fortnightly sampling, increasing to weekly sampling when abundances are higher than the species alert threshold $\left(10^{4}\right.$ cells $\mathrm{L}^{-1}$ for $A$. minutum). In addition, data from other research projects carried out by IFREMER or Station Biologique Roscoff (CNRS) were acquired. For quantitative phytoplankton analysis, lugol-preserved samples were counted with an inverted microscope (Utermöhl, 1958). Only surface samples (0-1m) were retained. Many environmental parameters were added to A. minutum counts. Water temperature $\left({ }^{\circ} \mathrm{C}\right)$ and salinity (PSU) were obtained in situ at the same sampling point with a portable probe, although not for all samples. Water samples $(100 \mathrm{ml})$ were also taken occasionally for inorganic nutrient analysis with Niskin bottles (5 L). They were stored at $-20^{\circ} \mathrm{C}$ until the analysis within the following month from the sampling. An autoanalyzer (Technicon III) was 
used following standard protocols (Hydes et al., 2010). Only $\mathrm{NO}_{3}{ }^{-}+\mathrm{NO}_{2}{ }^{-}$and $\mathrm{PO}_{4}{ }^{3-}$ was used in this study. Data from the other inorganic nutrients $\left(\mathrm{NO}_{3}{ }^{-}, \mathrm{NO}_{2}{ }^{-}, \mathrm{NH}_{4}{ }^{+}\right.$and $\left.\mathrm{SiO}_{4}{ }^{2-}\right)$ were discarded because they were scarce.

Daily river flow data were obtained from the data centre for French coastal operational oceanography (CDOCO). One river is assigned to each station based on the situation and its plume influence. Tidal influence in the ecosystem is integrated with two measures, the tidal coefficient and the tidal range. Daily tidal range is calculated from vertical difference between the high tides and the succeeding low tides of each day. Tides were acquired from the WXTide32 software (Flater). Tidal coefficient is a relative measure of the daily tidal range. This parameter enables easy identification of the neap-spring cycle, and varies between 20 (neap tide minimum) and 120 (spring tide maximum). Daily values are all the same for the French English Channel - Atlantic coast. It is calculated by the SHOM (Service Hydrographique et Océanographique de la Marine). When two tidal cycles coincided in one day, their mean was used as the tidal value of that day.

Meteorological variables used in this study were daily wind velocity $\left(\mathrm{m} \mathrm{s}^{-1}\right)$ and direction $\left(^{\circ}\right)$ and daily atmospheric pressure (hPa). They were acquired from two numerical models operated by MétéoFrance: Aladin and Arôme (Seity et al., 2011). The Aladin model has a space and time resolution of $15 \mathrm{~km}$ and 6 hours, respectively, and was used from $3^{\text {rd }}$ July 1997 to $11^{\text {th }}$ October 2011. The Arôme model has a space and time resolution of $2.5 \mathrm{~km}$ and 1 hour, respectively, and was used from $12^{\text {th }}$ October 2011 to 18 th November 2014 . The coherence between both models was tested with a correlation analysis. It was applied for a half-year period, in which both models were active (between October 2011 and March 2012). Models showed high coherence for wind and atmospheric pressure (uwind: $\mathrm{R}=0.88$; vwind: $\mathrm{R}=$ 0.85; atmospheric pressure: $\mathrm{R}=0.99 ; \mathrm{n}=21360)$. 
Daily Sea Surface Irradiance (SSI) was derived from METEOSAT visible imagery and daily Sea Surface Temperature (SST) was derived from the Advanced Very High Resolution Radiometer (AVHRR, Le Borgne et al., 2006a, 2006b). The situation of the stations inside bays or estuaries made the direct assignation of data from SSI and SST pixels difficult due to the lack of satellite data near the coast. In order to resolve this issue, the nearest pixel with sufficient data was assigned. SST data obtained were highly correlated with in situ water temperature $(\mathrm{R}=0.93, \mathrm{n}=857, \mathrm{p}<0.001$; Guallar et al., 2015).

Time-Series (TS) of daily variables with gaps were completed with interpolated values with a maximum of 5 days as a maximum of consecutive missing values to fill. Interpolation in longer gaps could underestimate variability in the data when trends are not linear (Cole et al., 2012).

\subsection{Phenology analysis}

For the phenology analysis, $A$. minutum TS were split by years and stations. They were logtransformed $\left(\mathrm{y}^{\prime}=\log _{10}(\mathrm{y}+1)\right)$ to compensate for the large weight of the extreme values in the analysis. To avoid incomplete or low quality TS, only those with more than eight samples and at least one of them with a value higher than $10^{4}$ cells $\mathrm{L}^{-1}$ (A. minutum alert threshold value according to REPHY) were selected. Subsequently, nine-phenology variables were extracted (Figure 1).

The Maximum Abundance (MA) and the Day of the Maximum Abundance (DMA) were directly obtained from the TS. To obtain the Day of the Bloom Start (DBS) and the Day of the Bloom End (DBE), a slightly modified methodology of Rolinski et al. (2007) was applied using the cardidates package for R. It is based on a Weibull function extended to the product (eq.1) to obtain a model of the bloom. Originally, it fits six parameters to obtain the model: (a) the species abundance in the beginning of the increasing phase; (b) the inflexion point of the increasing phase; $(c)$ the shape parameter of the increasing phase; $(d)$ the species 
abundance at the end of the increasing phase; $(e)$ the inflexion point of the decreasing phase and $(f)$ the shape parameter of the decreasing phase. In our study, due to the characteristics of the A. minutum blooms, where the species is absent before the bloom, the parameter $(a)$ was fixed to denote zero abundance at the beginning of the model.

(eq.1) $w(x)=\left(d+\exp \left(-(x / e)^{f}\right)\right) \times\left(1-a \exp \left(-(x / b)^{c}\right)\right)$

Once the model is fitted, the area under the curve was measured as the integral of the daily values. It was calculated separately before and after the DMA. To begin with, DBS denoted the date of the $10^{\text {th }}$ percentile of the area before the DMA, and DBE denoted the date of the $90^{\text {th }}$ percentile of the area after the DMA. Percentiles were determined by a trial and error procedure and coincided with those used by Rolinski et al. (2007).

Once DBS and DBE were obtained, the derived parameters were calculated: Bloom Length (BL), subtracting DBS from DBE; Increasing Length (IL), subtracting DBS from DMA; Decreasing Length (DL), subtracting DMA from DBE.

The Steepness Increase (SI) was calculated with the following equation:

(eq.2) $S I=\log \left(M A / x_{0}\right) / I L$

where $S I$ is the Steepness Increase, $M A$ is the species Maximum Abundance of the bloom, $x_{0}$ is the abundance at the beginning of the bloom determined by the Weibull procedure, and $I L$ is the length of the increasing phase of the bloom.

The Steepness Decrease (SD) was calculated with the following equation:

(eq.3) $S D=\log \left(x_{e} / M A\right) / D L$

where $S D$ is the Steepness Decrease, $x_{e}$ is the species abundance at the end of the bloom determined by the Weibull procedure, $M A$ is the Maximum Abundance of the bloom, and $D L$ is the length of the decreasing phase of the bloom. 


\subsection{Phenology variables dataset}

The environmental variables of the primary data set were added to the phenology variables, only retaining the values related with the cardinal dates (DBS, DBE and DMA). Several descriptors of the environmental variables were calculated for each cardinal date. They include maximum, minimum, mean and weighted mean of the environmental variable for a period of three, five or seven days before and after the cardinal date. These descriptors were only calculated for those variables with daily data: SST, SSI, river flow, tidal range, tidal coefficient, atmospheric pressure and wind velocity and direction.

\subsection{Paralytic shellfish poisoning toxicity}

When available, PSP toxicity data in shellfish were acquired from REPHY or from the research projects. Toxin measurements were systematically carried out in shellfish when $A$. minutum abundances exceeded the alert threshold of 10000 cells $\mathrm{L}^{-1}$. The official sanitary threshold corresponds to $800 \mu \mathrm{g}$ saxitoxin (STX) equivalents/kg shellfish. Between 400 and $800 \mu \mathrm{g}$ saxitoxin (STX) equivalents/kg shellfish contamination is considered as low. Higher values set off the closure of the shellfish harvesting. Typically, the control stations for the $A$. minutum enumeration and PSP toxicity detection are not the same and the sampling dates do not match. In addition, the shellfish analysed were not the same in all samples. Therefore, to minimise these inconsistencies, several PSP stations in the proximity of A. minutum stations were selected. Subsequently, a window of three days before and after the DMA was defined. Finally, the maximum PSP toxicity value that matched these criteria was chosen, without taking into account the shellfish species analysed. In the final results, the PSP toxicity data came from the analysis of five different shellfish species: Cerastoderma edule, Crassostrea gigas, Donax trunculus, Mytilus edulis and Mytilus galloprovincialis. 


\subsection{Relation between $A$. minutum phenology and the environment}

To explore the meaning of the phenology variables and try to understand the bloom dynamics of $A$. minutum, all the environmental variables were tested as fixed parameters using several types of models, including tree models, multiple linear models and log-log models. Only the environmental data registered before the phenology variable was used to develop the models. In the case of the MA parameter, it was included as an independent variable of the model developed.

The variable automatic selection procedure to obtain the models was performed with the Smoothly Clipped Absolute Deviation methodology (SCAD; Fan Jianqing, 2001) implemented in the ncvreg $\mathrm{R}$ package.

\subsection{Threshold variable analysis}

A scatterplot of the A. minutum abundances versus the environmental variables was made to test whether they play a role in the blooms or species development. Environmental thresholds were defined for abundance values of $10^{2}, 10^{4}$ and $10^{6}$ cells $\mathrm{L}^{-1}$. The first threshold was chosen as a representation of species absence-presence, whereas the second one corresponds to the alert threshold for this species and the latter is the definition of massive bloom in the Water Framework Directive. In order to achieve these results, the $1^{\text {st }}$ and $99^{\text {th }}$ percentile of the constraint variable at these abundances were calculated to avoid rare values.

Consequently, thresholds for the upper and lower range values of the constraint variable were obtained (Figure 2). The more data points in the scatter plot, the stronger the interpretation of the threshold. This analysis was applied at a global (all available data) or regional (for each REPHY region considered) scale.

Thresholds were obtained from several environmental variables: temperature in situ, salinity, river flow rate, tidal coefficient, SSI, wind and pressure. For the river flow rate, a $\log _{10}$ transformation was applied and when all available values were used, a standardisation of the 
values between 0 and 1 was also applied after the $\log _{10}$ transformation to minimise the regional/local effect of the river.

\subsection{Bloom development conditions}

The evolution of each bloom was studied in relation to the environmental variables. In order to do so, the variables were categorised according to a grey scale with shading lines (or colour scale in on-line version and in supplementary information). For the variables with validated threshold values, the same number of categories was defined as threshold values obtained, plus one. The maximum number of categories is seven: bad, regular and good for the upper and lower range of the variable and optimum conditions (Figure 2). For those variables for which the threshold was not validated, four intensity categories were defined: Low, Moderate, High and Very high. The boundaries were obtained calculating the quartiles of all available values.

Subsequently, TS curves of $A$. minutum blooms with the corresponding cardinal dates were plotted. In the same plot a five-day grid of grey scale with shading lines (or coloured scale in on-line version or in supplementary information) rectangles for each environmental variable was created. Each row presents 73 rectangles. For each rectangle, the five-day mean value of the corresponding variable was calculated. Then the rectangle was coloured according to the category it represents (threshold values or intensity scale).

Finally, the PSP toxicity was also represented. Two threshold values (400 and $800 \mu \mathrm{g}$ saxitoxin (STX) equivalents/kg shellfish) and three categories (no toxicity, low toxicity and high toxicity) were defined. For each phytoplankton station only the stations nearby with toxicity analysis were assigned. In this case, the maximum value of the $5 \mathrm{~d}$-week period was chosen, independently of the shellfish species analysed. 


\subsection{Data analysis}

All analyses, graphical representations and models were performed with the R software (R. C. Team, 2015) using the RStudio interface (Rs. Team, 2015).

\section{Results}

\subsection{Time-series selection}

The data used for this study were from the French English Channel - Atlantic coast.

According to the selection criteria, a total of 53 TS were obtained to study the phenology of $A$. minutum blooms. They encompass 16 stations from nine different regions (or water masses) from the REPHY sampling strategy: Rance Estuary, Morlaix Bay, Penzé Bay, Abers (Aber Benoit and Wrac'h), Brest Bay, Douarnenez Bay, Vilaine Bay, Pen Bé Bay and Olerón Bay (Figure 3). All regions are partially enclosed ecosystems.

The station with the most TS was Rance Estuary (twelve TS from 1996 to 2011). Morlaix Bay was the region with the most records, with 15 TS from three different stations: Locquenolé (eight TS from 1991 to 2013), Pen al Lann (six TS from 1989 to 2010) and Lannuguy (one TS from 1991). Penzé Bay presented eight TS (1989-1996). From the Abers region, two stations were from Aber Benoit (Prat ar Coum, one TS from 1989; and Keramoal, two TS from 1995 and 1999) and one from Aber Wrac'h (Paluden, two TS from 1995 and 2013). Brest Bay presented four different stations: Pointe du Château (five TS from 2009 to 2014), Le Passage (one TS from 2014), Lanvéoc Large (one TS from 2014) and Lanvéoc (one TS from 2014). Oléron Bay presented two TS from 1997 and 2003. Finally, Douarnenez Bay, Vilaine Bay and Pen Bé Bay had one TS each (one TS from 2002, one TS from 2010, and one TS from 2002, respectively).

The phenology variables of the decreasing phase from four TS were discarded due to a lack of samples at the end of the bloom (Locquenole from Morlaix Bay in 2013, Paluden from Abers 
region in 2013 and Le Passage and Lanvéoc stations from Brest Bay in 2014; Suppl. Information 1).

\subsection{Comparison of environmental data in the nine regions}

The nine regions studied have a similar seasonality for irradiance, with a maximum of around $250 \mathrm{~W} \mathrm{~m}^{-2}$ in the middle of the year (June), and a minimum of approximately $40 \mathrm{~W} \mathrm{~m}^{-2}$ in the beginning and in the end of the year (January to December, Figure 4A). The water temperature also has a similar seasonality, slightly lagged compared to irradiation, with a maximum of approximately $20^{\circ} \mathrm{C}$ in July, and a minimum of approximately $10^{\circ} \mathrm{C}$ in February. Some differences were found between regions: Oléron Bay, located in the southernmost latitude, presents the highest water temperatures, followed by the Pen Bé Bay, the Vilaine Bay and Rance Estuary. The Abers region presents the lowest water temperature in summer, although it is the region with the highest water temperature in winter (Figure 4C). River flow presents the same annual cycle for all regions with an opposite oscillation compared with water temperature seasonality (Figure 4E). February has the maximum river flow coinciding with the lowest water temperature, whereas the minimum river flow is in July, coinciding with the highest water temperature. Differences were found between the magnitudes of the river flow among regions. Vilaine River presents the highest flow rate, which influences Vilaine Bay and Pen Bé Bay; followed by the Charente River, in Oléron Bay. Following, in descending order, are the Penzé (Penzé Bay), Queffleuth (Morlaix Bay), Mignonne (Brest Bay) and Rance (Rance Estuary) rivers. Finally, the lowest flow rate is from the Aber Benoit River in the Abers region. No river is assigned to the Douarnenez Bay. The magnitude of the tidal range is different between regions (Figure 4B). Rance Estuary has the highest variation (from two to 13 metres) compared to the other regions. The lowest tidal ranges correspond to the regions of Pen Bé Bay and Vilaine Bay (between two and six metres). The remaining regions present tidal ranges between two and seven metres. 
Relative to wind velocity distribution, Morlaix Bay presents the highest value dispersion followed by Penzé Bay, Oléron Bay, the Abers region, Pen Bé Bay, Vilaine Bay, Brest Bay, Douarnenez Bay and Rance Estuary (Figure 4D). All the regions present many possible outliers in the upper range values. In general, wind velocities are lower in summer and higher in winter (data not shown).

According to the salinity boxplot (Figure 4F), Douarnenez Bay is the region with the lowest variability and the least influenced by freshwater inputs. Penzé Bay, in contrast, presents the widest dispersion of salinity values, without taking into account the possible outliers, meaning that it is highly influenced by freshwater inputs. All regions present possible outliers mainly in the low salinity values.

Nutrient data shows high variability between regions (Figure 4G and H). Penzé Bay has in general a high range of values in phosphate and inorganic nitrogen. Rance Estuary also presents a high range of values for phosphate but low range values for inorganic nitrogen. Contrary, the Abers region has a high concentration range for inorganic nitrogen but a moderate range of values for phosphate concentration. Next, Morlaix Bay and Brest Bay have a moderate range of concentration for phosphate and inorganic nitrogen and, finally, Douarnenez Bay has the lowest range values for nutrient concentrations. Nutrient data for Vilaine Bay, Pen Bé Bay and Oléron Bay do not exist.

Atmospheric pressure does not present seasonal peculiarities or differences between regions (data not shown).

\subsection{Phenology parameters}

Figure 5 shows a summary of the phenology parameters obtained (See Suppl. Figure 1 for a graphical representation of the $53 \mathrm{TS}$ analysed). 
The highest MA of A. minutum in the TS studied was $7.98 \cdot 10^{6}$ cells $\mathrm{L}^{-1}$. It was in Penzé Bay in 1994. The lowest MA was $1.02 \cdot 10^{4}$ cells $\mathrm{L}^{-1}$ in 1994 in Pen al Lann (Morlaix Bay). The middle half distribution of this parameter was between $2.6 \cdot 10^{4}$ cells $\mathrm{L}^{-1}$ and $4.9 \cdot 10^{5}$ cells $\mathrm{L}^{-1}$. The mean BL of this study was 76.5 days and its middle half distribution was between 51 days and 102 days. The TS of Pointe du Château (Brest Bay) in 2014 is a possible outlier with a BL of 181days. The mean IL was 40.5 days and its middle half distribution was between 23 days and 54 days. The mean DL was 36.6 days and its middle half distribution was between 20 days and 52 days.

The middle half distribution of the DBS was between the $135^{\text {th }}$ day of the year $\left(15^{\text {th }}\right.$ May) and the $167^{\text {th }}\left(16^{\text {th }}\right.$ June). The middle half distribution of the DMA was between the $178^{\text {th }}$ day of the year $\left(26^{\text {th }}\right.$ June) and the $203^{\text {rd }}\left(22^{\text {nd }}\right.$ July). The TS of Paluden (Abers region) in 2013 is a possible outlier for this phenology parameter with a value of 245 ( $2^{\text {nd }}$ September). The middle half distribution of the DBE was between the $211^{\text {th }}$ day of the year $\left(30^{\text {th }} \mathrm{July}\right)$ and the $241^{\text {st }}$ ( $29^{\text {th }}$ August). The TS of Oléron Bay in 1997 is a possible outlier in the lower range values of this phenology parameter with a value of $163\left(12^{\text {th }}\right.$ June).

The middle half distribution of the SI parameter was between 0.18 days $^{-1}$ and 0.39 days $^{-1}$. Five values with SI $>0.71$ days $^{-1}$ were possible outliers. They were from Rance Estuary in 1996 (1.33 days $\left.{ }^{-1}\right)$, Locquenolé (Morlaix Bay) in 1995 (0.81 days $\left.{ }^{-1}\right)$, Penzé Bay in 1996 (2.32 days $^{-1}$ ), Pen Bé Bay in 2002 (2.14 days $\left.{ }^{-1}\right)$ and Oléron Bay in 1997 (0.78 days $\left.{ }^{-1}\right)$. The middle half distribution of the SD parameter was between -0.14 days $^{-1}$ and -0.37 days $^{-1}$. The TS of Oléron Bay in 1997 is a possible outlier with a SD value of -0.79 .

An inverse relation exists between SI and IL $\left(\mathrm{IL}\right.$ and $\left.\mathrm{SI}^{-1}, \mathrm{R}=0.95\right)$ as well as between SD and DL (DL and SD ${ }^{-1}, \mathrm{R}=-0.86$; Suppl. figure 2). 


\subsection{Relation between $A$. minutum phenology and the environment}

Using a multiple linear regression, the IL model obtained an accuracy of $R^{2}=0.80$ (p-value < $0.001, \mathrm{n}=49$; Table 1, Figure $6 \mathrm{~A})$. The environmental variables used to perform the model were weekly SST of the DBS, presenting the highest influence on the model with a negative interaction; the weekly SST of the DMA, with a positive influence; and the mean river flow three days before the DMA, with the lowest and negative influence on the IL parameter. The weekly mean SST of the DBS is highly correlated with the mean water temperature of the increasing phase of the bloom calculated from SST data $(\mathrm{R}=0.87)$ and a similar result was obtained changing this variable in the IL model $\left(R^{2}=0.72\right)$.

Due to the relation between SI and IL parameters, a model with the same environmental variables but using the inverse of SI as a dependent variable was performed. Significant results were obtained $\left(\mathrm{R}^{2}=0.72, \mathrm{n}=46, \mathrm{p}<0.001\right.$; Table 2 , Figure $\left.6 \mathrm{~B}\right)$. In addition, weekly mean SST of the DBS is significantly correlated with the shape parameter of the increasing phase of the Weibull function (parameter $c$ in eq.1; $\mathrm{R}=0.73, \mathrm{n}=53, \mathrm{p}<0.001$ ). The higher the shape parameter, the shorter and the higher the curve produced, which is the same relationship seen between SI and IL.

For the MA parameter, no statistical model was obtained. According to the SI equation (eq. 2), MA values may be obtained using SI, IL and the species abundance at the DBS ( $\mathrm{x}_{0}$ parameter in eq. 2). The SI and IL parameters were modelled in this study and the importance of the $\mathrm{x}_{0}$ parameter is minimal in determining the MA (Estrada et al., 2010). Therefore MA values may be achieved with the model results of SI and IL. Nevertheless, no significant results were obtained. Better model accuracy for SI and/or IL is needed to obtain MA by means of equation (2).

For the decreasing phase we only found a positive relationship between the DL parameter and the mean water temperature of the decreasing phase with a clear outlier, corresponding to the 
bloom of Oléron Bay in 2003 (including the outlier: $\mathrm{R}=0.47, \mathrm{n}=49, \mathrm{p}<0.001$; excluding the outlier: $\mathrm{R}=0.58, \mathrm{n}=48, \mathrm{p}<0.001$; Suppl. figure 3A). The same behaviour is obtained with the inverse of SD and the mean water temperature of the decreasing phase (including the outlier: $\mathrm{R}=-0.45, \mathrm{n}=49, \mathrm{p}=0.001$; excluding the outlier: $\mathrm{R}=-0.53, \mathrm{n}=48, \mathrm{p}<0.001$; Suppl. figure 3B).

A significant model for the shellfish PSP toxicity concentration ( $\log _{10}$ transformed) was developed. The $\log _{10}$ transformed MA was an independent variable with a positive influence. The other independent variable used was the minimum standardised river flow five days before the DMA, also with a positive influence on the PSP toxicity. A multiple linear regression was performed obtaining the following result: $\mathrm{R}^{2}=0.49$, $\mathrm{p}$-value $<0.001, \mathrm{n}=36$ (Table 3, Figure 6C).

\subsection{Threshold values}

Only the environmental variables with interesting threshold results were shown, i.e. temperature in situ, tidal coefficient, river flow and nutrients (see Suppl. figure 4 for the representation of the environmental variables not validated by the threshold analysis). For the temperature in situ, only the threshold values in the lower range were considered for all the available data. The $10^{2}$-threshold value was $9.7^{\circ} \mathrm{C}$, the $10^{4}$-threshold value was $14.4^{\circ} \mathrm{C}$ and the $10^{6}$-threshold value was $15.7^{\circ} \mathrm{C}$ (Figure $7 \mathrm{~A}$ ). The upper range threshold values were discarded because of the lack of sufficient samples with high temperature in situ values. The threshold values for the regions were similar to global threshold values.

For the tidal coefficient, only $10^{6}$-threshold values of the global study were considered. For the lower range, the $10^{6}$-threshold value was 38 and for the upper range it was 81 (Figure 7B). The regional threshold showed similar behaviour to the global figure and $10^{2}$ and $10^{4}$ threshold values on the lower and upper ranges present insufficient data. 
All river flows show the same pattern of influence on A. minutum abundance, with an optimal effect when the river flow intensity is medium. Good, moderate and bad effects were achieved when river flow decreased or increased from the optimum. This is a general effect, although local characteristics define different threshold values from one river to another (Figure 8). Regarding nutrients, threshold analysis was carried out in Penzé Bay. The analysis of the other regions was discarded due to the low number or lack of data (Figure $4 \mathrm{G}$ and $\mathrm{H}$ ). Only the threshold values for the lower range were displayed. For phosphate, threshold values for $10^{2}$ and $10^{4}$ cells $\mathrm{L}^{-1}$ were the same and very low $(0.02 \mu \mathrm{M})$, near the minimum value measured in the data set $(0.01 \mu \mathrm{M})$. The $10^{6}$ cells $\mathrm{L}^{-1}$ threshold value is slightly higher $(0.07$ $\mu \mathrm{M}$, Suppl. figure 5A). Nitrogen threshold values were $14.7 \mu \mathrm{M}, 18.2 \mu \mathrm{M}$ and $98 \mu \mathrm{M}$ for $10^{2}$ cells $\mathrm{L}^{-1}, 10^{4}$ cells $\mathrm{L}^{-1}$ and $10^{6}$ cells $\mathrm{L}^{-1}$, respectively (Suppl. figure 5B).

\subsection{Bloom development conditions}

Several years of three stations with interesting TS were analysed: Pen al Lann (Morlaix Bay), Penzé Bay and Pointe du Château (Brest Bay).

In Pen al Lann (Figure 9), maximum abundances in the 1989 bloom (> 10 $0^{4}$ cells $\mathrm{L}^{-1}$ ) cooccurred with optimum conditions of temperature, river flow and tidal coefficient for $A$. minutum (5d-week 33-39). The first environmental variable to lose the optimum condition was the river flow rate that decreased from optimum to good condition in 5d-week 40 which coincided with the termination of the bloom. Subsequently, tidal coefficient also increased from optimum to good condition in the 5d-week 41. In 1993, bloom started before and the increasing length lasted longer than 1989 as environmental conditions were not optimal, high river flow (regular) and irradiance remained low. The bloom started to diminish with a strong decrease in irradiance (from very high to moderate conditions) and with a high level of tidal coefficient. In 1994, two isolated abundances of around 100 cells $\mathrm{L}^{-1}$ were enumerated before the start of the bloom. In the increasing phase of the bloom, the optimum conditions in 
temperature and river flow rate were displaced in time and coincided later (high river flow from bad to good and low temperature from regular to good). On week 44, MA occurred after all parameters in optimum conditions with very-high levels of irradiance during the three 5dweeks (42-44). Irradiance decreased then to moderate intensity, which coincided, with bloom decrease. Several periods of high tidal coefficient conditions seemed to decrease momentarily the species abundance. This year, the bloom was displaced later in time and the maximum abundance reached was lower.

In Penzé Bay (Suppl. figure 6), the five years represented show a similar pattern with MA occurring after the first or second five-day period where the three environmental parameters (temperature, river flow and tide) were optimal and irradiance was high or very high. This may explain the variation of the DMA, linked to the occurrence of optimal conditions earlier in 1990, later in 1991). The isolated count of approximately 100 cells $\mathrm{L}^{-1}$ observed before the bloom in certain years may be explained by the lack of optimal conditions for growth. Bloom decline is accompanied by decreased river flow (good to bad conditions) and also affected by increasing tides (becoming good). The bloom intensity (MA) varied from one year to another. In 1991, the low MA seemed linked to non-optimal conditions and moderate irradiance that lasted all spring.

In Pointe du Château (Brest Bay, Suppl. figure 7), MA occurred for optimal temperature. 2012 presents the highest MA and also high to very high river flow in spring and July. 2013 shows the lowest MA and the bloom length in 2014 was the longest of the three years. Twenty-six out of 53 blooms analysed were considered toxic blooms (shellfish PSP content $\geq$ $400 \mu \mathrm{g}$ STX equivalents/kg shellfish) and 14 were non-toxic blooms (shellfish PSP content < $400 \mu \mathrm{g}$ STX equivalents/kg shellfish). For the remaining 13 blooms data were either absent or did not present PSP data during the period of maximum abundance of the bloom. In all toxic blooms, the maximum PSP concentration was found during the period of the bloom with the 
maximum abundance of $A$. minutum. Only the Pointe du Château station in 2014 presented the maximum PSP concentration before the maximum abundance of the bloom, although similar abundances to that of the maximum abundance were reached during the maximum toxicity period.

\section{Discussion}

\subsection{Methodology and data set}

The main objective of the REPHY is not to provide big data sets for their global analysis and some issues arose while using it for modelling phytoplankton blooms. Solid long TS are hardly acquired due to the sampling strategy. Consequently, as phytoplankton is irregularly distributed in space and evolves in time, it is difficult to obtain a true representation of the bloom evolution in the ecosystem. These sampling errors may be minimised using smoothing or curve fitting methods (Ji et al., 2010 and references therein), such as the Weibull fitting method (Rolinski et al., 2007).

Only DBS and DBE were used from the Rolinski methodology because the low frequency data and the low abundance values in these periods of the bloom make them vulnerable to observational noise resulting in possible biases and poor decision (Ballabrera-Poy et al., 2003; Behrenfeld et al., 2013; Cole et al., 2012; Maritorena and Siegel, 2005; Verbesselt et al., 2010). In contrast, DMA and MA were obtained directly from monitoring data due to the highest sampling frequency and amplitude of the bloom during this period. These characteristics increase the accuracy of the metrics obtained (Ferreira et al., 2014). In addition, MA obtained from the Weibull model was lower due to the smoothing property of the curve fitting procedures (mean MA from Weibull model: 4.5; mean MA from raw data: 5.1).

The prior logarithmic transformation of the abundances reduced the extreme weights of the higher values. Otherwise, they constrained the real area integration. Rolinski et al. (2007) did 
not apply a prior transformation, although they worked with chlorophyll concentration data, with a range of one degree of magnitude. In contrast, using this method, bloom area between 0 and 100 cells $\mathrm{L}^{-1}$ enlarges their weight. This problem is minimised with the percentiles chosen for the integration of the bloom area.

In the literature, length duration phases were mainly determined by visually estimating the cardinal dates (Anderson et al., 2012; Garcés, 2004). Others used a threshold abundance to delimit the bloom based on a baseline (Beliaeff et al., 2001) or biomass accumulation (Greve et al., 2005).

Finally, SI and SD were determined for the whole period of increasing and decreasing phases of the bloom, respectively. Therefore, apart from exclusively in situ growth rates other processes were also included (concentration or dilution, grazing, parasites infection, encystment, germination). In the literature, they are also calculated as instantaneous rates from high frequency sampled abundance data (Mieruch et al., 2010); although they are mainly obtained from culture experiments (Chang and McClean, 1997; Grzebyk et al., 2003; among others).

Typically, monitoring programmes collect environmental data at the same time as phytoplankton data and a few studies were carried out only using the monitoring variables (Cusack et al., 2015; Wiltshire et al., 2008). In our study, we completed REPHY monitoring data with additional variables that we found in other datasets with different sampling frequency. For instance, nutrient data only permit to carry out the threshold analysis for Penzé Bay and do not allow using it to explain the phenology analysis. To complement the data set, when possible, external sources were then acquired. Model outputs were used to obtain meteorological or hydrographical information, as in Gonzalez-Vilas et al. (2014). Others used in situ data from parallel monitoring programmes (Guallar et al., 2016). All of these studies were focused at most within a unique coastal region. Here, as the stations studied encompass 
almost all the French English Channel - Atlantic coasts, external information was gathered from in situ data, such as the river flow information; model outputs, as the meteorological or tidal range or tidal coefficient data; or from satellite, such as the SST or SSI.

Missing data may be present in TS. Linear interpolation is a useful procedure to avoid these gaps when they are scarce, as in Cusack et al. (2015); but longer gaps were present in coastal data obtained from satellite. The station selection criteria used to assign external data to TS, and in addition to select the nearest data point, included an algorithm to avoid grid points with long gaps.

Shellfish toxin content data used was not obtained at the same station as phytoplankton samples. In addition, the shellfish species analysed could differ depending on the shellfish station used. A standardised procedure should recommend normalising data from different shellfish species (Bricelj and Shumway, 1998), as did Trainer et al. (2003), and monitoring the toxin concentration in the water at the same time and same station as phytoplankton sampling would be preferable. As a consequence, the insufficient quality and quantity of data did not allow us completing this analysis.

All these situations restricted the amount of available data and most likely affected the accuracy and the precision of the metrics obtained (Ferreira et al., 2014), limited the information used for the analysis (variables and amount of data) and restricted the cases used in the developed models of bloom parameters.

The other methodology implemented here was the environmental threshold analysis combined with their representation in the bloom evolution. Similar methodologies exist in the literature. Husson et al. (2016) extracted the environmental characteristics of the niche region corresponding to the 5\% most abundant Pseudo-nitzschia spp. occurrences, but they did not relate the values of abundance (i.e., the three threshold abundances defined herein) to environmental characteristics. In addition, as this analysis is carried out with several 
environmental variables at the same time, data sets with missing values lost a portion of the information in the analysis. In another study Irwin et al. (2012), used presence-absence data to determine the realized niche of phytoplankton species for one environmental variable at a time, but no categorisation of the environmental variables was obtained.

\subsection{Dynamics of $A$. minutum blooms}

In the present study the bloom definition is determined following the criteria established by Smayda (1997) concerning HABs, i.e., when the species is present in the water column and exceeds a certain cell concentration that entails harmful consequences. In the case of $A$. minutum along the French coasts, the REPHY monitoring programme determined an alert threshold of $10^{4}$ cells $\mathrm{L}^{-1}$.

Phenology results show a similar trend for all A. minutum blooms along the French English Channel - Atlantic coast: only one bloom per year is measured, MA (Maximum Abundances; Figure 1) may reach more than $10^{6}$ cells $\mathrm{L}^{-1}$, the bloom period extend from April to October and the BL (Bloom Length; Figure 1) ranges from two weeks to six months. Although the highest MA obtained in the TS studied was in the order of $10^{6}$ cells $\mathrm{L}^{-1}$, eight different blooms not analysed due to absence of sufficient data but included in the primary data set reached $10^{7}$ cells $\mathrm{L}^{-1}$ (maximum of $4.46 \times 10^{7}$ cells $\mathrm{L}^{-1}$ recorded in the Penzé Bay in 1997, Suppl. figure 8). These data are in the range of the MA values found in the literature. Examples from other regions with similar MA are Arenys de Mar harbour in the NW Mediterranean Sea $\left(4.7\right.$ x $10^{7}$ cells $L^{-1}$; Garcés, 2004) or Alexandria in Egypt (2.4 x $10^{7}$ cells

$\mathrm{L}^{-1}$; Labib and Halim, 1995). Other regions reached lower values, as in Cork Harbour (Ireland, $1.7 \times 10^{6}$ cells L ${ }^{-1}$; Cosgrove et al., 2014). The maximum cell concentration registered for this species was $1.4 \times 10^{8}$ cells $\mathrm{L}^{-1}$, measured in Cape Town harbour (South Africa; Pitcher et al., 2007). 
The BL herein is not so different from those found elsewhere. In Galician Rias or in Cork Harbour, blooms of less than one month are described (Bravo et al., 2010; Cosgrove et al., 2014) and Giacobbe et al. (1996) studied an A. minutum bloom of six months in the Ganzirri lagoon (Mediterranean Sea). The methodology applied here to detect them simplifies its population dynamics due to the smoothing property. A detailed analysis of bloom evolution showed some periods where rapid cell increase stopped and cell abundance diminished temporally. This may be interpreted as an independent blooms or losses linked to a dilution of the population by the currents (Chapelle et al., 2015; Raine, 2014; Sourisseau et al., 2017). In addition, Dia et al. (2014) reveals high genotypic and genetic diversity in blooms of this species, and therefore, the definition of bloom considered here may also be interpreted as a succession or co-occurrence of blooms from different genetic populations of the same species. Increasing Length (IL; Figure 1) and Decreasing Length (DL; Figure 1) range from 4 to 101 and from 4 to 86 days, respectively. Although it seems that blooms were symmetric, typically they showed large differences between data pairs (mean of absolute values of differences between both phases is 18.8 days). This suggests that the main processes involved in both phases differ or are different in magnitude.

A window of occurrence of A. minutum blooms in the French English Channel - Atlantic coasts could be defined. The DBS (Date of Bloom Start; Figure 1) extends from April to August, with the DMA (Date of Maximum Abundance; Figure 1) of the bloom between May and September, and a DBE (Date of Bloom End; Figure 1) between June and October. A similar but more restricted window of occurrence is defined in Cork Harbour expanding from June to the end of September and peaking in June-July (Cosgrove, 2014; Cosgrove et al., 2014). These cardinal dates are significantly different in the Mediterranean Sea. For example, in Arenys de Mar (Catalan coast) and in Syracusa (Sicily) two recurrent blooms of $A$. 
minutum per year take place from winter to spring and in summer (Mediterranean Sea; Vila et al., 2005).

Maximum SI (Steepness Increase; Figure 1) and minimum SD (Steepness Decrease; Figure 1) values measured in the present study were $2.32 \mathrm{~d}^{-1}$ and $-0.79 \mathrm{~d}^{-1}$, respectively. The highest value found in the literature for SI was $1.3 \mathrm{~d}^{-1}$, measured with the diffusion cages method by Garcés et al. (1998) in Arenys de Mar harbour; and for SD was $-0.84 \mathrm{~d}^{-1}$, calculated with the dilution method (Calbet et al., 2003) in the same location. Several SI and one SD values obtained here are higher than or have the same magnitude as those, respectively. The extreme values measured here also presented the shortest IL (between 4 and 9 days) and DL (4 days) of the study, respectively. They are the result of two consecutive samples with the values 0 and more than $10^{4}$ cells $\mathrm{L}^{-1}$ for the SI cases, or with the values more than $10^{4}$ cells $\mathrm{L}^{-1}$ and 0 cells $\mathrm{L}^{-1}$ for the SD case. Most likely, an inaccuracy inherent in the sampling and/or counting procedure induced these extreme values, due to advection processes or vertical migrations that moved the bloom in the vicinity of the sampling point. Furthermore, the values calculated with in situ abundances include other processes than growth rate. Moreover, the values found in the literature are mainly in situ growth rates resulting from culture experiments in the laboratory, where the forced growth conditions are far from those under which toxic blooms occur naturally (Cembella et al., 1988; Grzebyk et al., 2003; Ralston et al., 2014). As an example, Labry et al. (2008) measured in situ growth rates between $0.28 \mathrm{~d}^{-1}$ and $0.71 \mathrm{~d}^{-1}$ in culture experiments with an A. minutum strain isolated from Morlaix Bay. A high inversed relationship is detected between the parameters IL and SI and between DL and SD. To our knowledge, these links have never been addressed before, considering that no study had previously focused on such a detailed description of the A. minutum bloom phenology. 


\subsection{Alexandrium minutum blooms and environmental control}

\section{Bloom initiation}

In the French English Channel - Atlantic coast, no A. minutum cells are observed in winter due to a lack of adequate conditions, as was the case in Cork Harbour (Cosgrove et al., 2014). In contrast, in Arenys de Mar harbour a continuous development of vegetative cells may exist throughout the year (Bravo et al., 2008). Bloom initiation may be due to offshore import of vegetative cells, as is the case for A. fundyense in the western Gulf of Maine (Anderson et al., 2005; McGillicuddy et al., 2003) or cyst germination. In the French English Channel Atlantic coast, A. minutum only develops blooms inside the estuaries and, according to Dia et al. (2014), these ecosystems are partially isolated during bloom events. Most probably, in the ecosystems studied bloom initiation requires excystment, as also suggested by Probert (1999) in the Penzé and Abers regions. The presence of cysts in sediments has been described in most of the sites studied here (Erard-Le Denn, 1997; Klouch et al., 2016).

To excyst, $A$. minutum cells need a mandatory period of maturation or cyst dormancy. According to Ni Rathaille and Raine (2011) this process presents seasonal influences and is variable in time (at least from one to three months; Figueroa et al., 2007). Temperature, oxygen and light are factors that may influence excystment (Anderson et al., 2012; Ní Rathaille and Raine, 2011). Once cells excyst, they should encounter the appropriate conditions for development. On several occasions, low abundances $\left(c a .10^{2}-10^{3}\right.$ cells $\left.\mathrm{L}^{-1}\right)$ were observed several weeks prior to bloom (i.e.: Figure 9C and Suppl. Figure 5B-E). Most likely, although excystment occurs, water column conditions may not be appropriate for their development. This indicates that a period of continuous inoculation of vegetative cells in the water column exists and those cells that meet the right conditions, may reach the exponential phase and develop a bloom. Cosgrove et al. (2014) showed that bloom intensity is not dependant on cyst abundance in Cork estuary. 
In the literature, temperature and dilution rate are the main variables used to model the DBS. Ralston et al. (2014) used the degree-day approach to model the bloom initiation of $A$. fundyense in the Nauset estuary, i.e., the accumulation of a certain temperature above a threshold. Additionally, in Cork Harbour, the initiation of the bloom occurs after the first large spring tide in June when water column temperatures are mainly above $15^{\circ} \mathrm{C}$ (Cosgrove et al., 2014). A numerical modelling study carried out with blooms from three consecutive years of Brest Bay highlight the importance of the water column temperature and the dilution rate to determine the bloom initiation (Sourisseau et al., 2017). In the present study, no significant model has been obtained for the DBS but the threshold analysis showed that $A$. minutum needs certain water column temperature and river flow characteristics (as a proxy of dilution rate, Raine, 2014) to bloom.

Similar to Cork Harbour, A. minutum develops blooms (over the alert threshold) when in situ temperature is higher than $14.4^{\circ} \mathrm{C}$ (Figure 7). This value is reached differently in time depending on the region (from SST data: mid-May in Olerón Bay to mid-July in Abers region; Figure 4C) and this may explain the large time-span of the DBS. For instance, the Abers region, with the coldest water in summer, presents the last DBS in this study, comparable to DBS of Cork Harbour, with similar temperature conditions (Cosgrove et al., 2014).

In all regions studied, the window period of DBS coincides with the decreasing of the river flow (Figure 4E) and the threshold analysis determines a maximum value in the upper range linked to a dilution effect that allows the development of bloom abundance levels (Figure 8). The maximum value is region-dependent and thus most likely renders the development of a general model for the DBS difficult in this study. 


\section{Bloom development}

In a semi-enclosed area where A. minutum develops, abundance increases only if the in situ growth rate exceeds the mortality and/or the flushing rate (Raine, 2014). Hydrodynamic currents created by tide, wind and river flow locally determine the flushing rate, thereby influencing bloom development (Anderson et al., 2012; Cugier and Le Hir, 2002; Laanaia et al., 2013; Raine, 2014; Sourisseau et al., 2017). In this study, the dilution effect resulting from high tides is significant (Figure 7B), affecting bloom abundances (i.e.: 5day-week 35 in Figure 9B or several times in Suppl. figure 7B). High river flows also show a negative effect on bloom abundances by promoting their dilution as commented before (Figures 8 and 9 in Morlaix Bay). Wind also affects bloom development. For instance, in Oléron in 2003 a period of five days with strong winds from the West apparently reduces cell concentration (daily average of $5 \mathrm{~ms}^{-1}$ and a maximum daily mean of $11.5 \mathrm{~ms}^{-1}$ on $5 \mathrm{~d}$-week 37 , Suppl. figure 9). The thermal or haline stratification of the water column and therefore its stability is also a key factor according to many studies and most likely determines the presence of the species mainly in estuaries or enclosed ecosystems (Anderson, 1998). The swimming behaviour of this species is an advantage to migrate between water layers to avoid predation and to search for nutrient rich water layers in stratified ecosystems (Wells et al., 2015). In this study, no stratification was observed mainly due to the high tidal range measured in the estuaries (Figure 4B). In addition, the abundance data used in the analysis comes from surface samples and the sampling frequency is lower than the tidal cycles, therefore the results obtained with them are not influenced by the stratification of the water column. This situation is similar in the Cork Harbour ecosystem (Raine, 2014). Contrary, in other ecosystems, as in the Mediterranean Sea, where the tidal range is practically absent (Vila et al., 2005, Giacobbe et al., 1996), the swimming advantage of A. minutum species is likely to be important. 
Factors that affect in situ growth rate are: nutrients, irradiance and temperature. Nutrient thresholds found for nitrate plus nitrite were high $(18.2 \mu \mathrm{M}$ for the alert threshold and $98 \mu \mathrm{M}$ for the $10^{6}$ cells $\mathrm{L}^{-1}$ threshold) but nitrate plus nitrite concentrations in Penzé Bay are very high (mean $166 \mu \mathrm{M}$, Figure 4H). Phosphate threshold values (i.e.: $0.07 \mu \mathrm{M}$ for the threshold abundance of $10^{6}$ cells $\left.\mathrm{L}^{-1}\right)$ are lower than mean phosphate concentration $(0.93 \mu \mathrm{M}$, Figure 4G). Therefore, nutrients probably do not limit the bloom development in this ecosystem. Similar conclusions were obtained in Maguer et al. (2004) in the same region, where nitrate was described as the key nutrient to sustain the $10^{7}$ cells $\mathrm{L}^{-1}$ bloom analysed.

In a general way, nutrient influence is derived from the river flow, a proxy of nutrient supply to estuaries (Romero et al., 2013). In this case the focus is on the lower range values. During bloom development, river flow decreases and as the threshold analysis shows, lower values limit cell concentration (Figure 8, i.e. Penzé, Suppl. figure 6). In fact, the positive effect of river flow at the DMA in the SI model may be interpreted as a nutrient limitation. In the same way, the plateau zone in the period surrounding the DMA seen in the biggest blooms is likely a consequence that the bloom has reached the carrying capacity of the ecosystem due to a possible nutrient limitation (i.e.: Suppl. figure 7; Chapelle et al., 2015). Irradiance also positively affects the growth of A. minutum (Chang and McClean, 1997). In general, it is not a limiting factor in our study (Suppl. figure 4B), but a diminution of irradiance coincides with an abundance decrease in some cases (i.e.: 5d-week 40 in Figure 9B). This general result is confirmed by a detailed analysis conducted in the Bay of Brest by Sourisseau et al. (2017).

Temperature is a key variable for the in situ growth rate. Several studies conducted in the laboratory confirm this strong relationship (Figueroa et al., 2007; Lim et al., 2006), which is also found in field studies that define temperature windows suitable for bloom development (Bravo et al., 2008; Chapelle et al., 2015; Delgado et al., 1990; Giacobbe et al., 1996; Raine, 
2014; Sourisseau et al., 2017). Ralston et al. (2014) state that due to the hydrographic and chemical characteristics of the Nauset estuary, temperature mainly determines the key moments of A. fundyense blooms.

According to the models developed in this study, temperature is also the most important factor affecting the increasing phase. Nevertheless, its influence depends on the period retained and the phenology parameter analysed. The positive influence of temperature at the DBS (or the mean temperature during the increasing phase) in SI is consistent with studies and observations that A. minutum blooms grow faster in higher temperatures. At the same time, higher temperature at the DBS (or higher mean temperature during the increasing phase) shortens the IL. This is also seen in laboratory experiments carried out with monoclonal $A$. catenella cultures where temperature seems to control the length of the IL (Navarro et al., 2006).

Here, temperature seems also linked to a process related to the shift between bloom increase and bloom decrease, and therefore to the beginning of the bloom termination. The induction of sexuality and cyst formation may be a process responsible for the finalisation of the increasing phase mediated by the temperature. The strong relationship between growth and cyst formation rates and temperature is seen in culture experiments for this species (Probert, 1999). In A. tamarense, both processes present an unimodal behaviour related to temperature and peaked at the same temperature value, but the ratio between cyst production rate and growth rate is not constant and it depends on the temperature (Figure 2 in Anderson et al., 1984). A possible hypothesis is that the shift between bloom increase and bloom decrease is an equilibrium between the processes of growth rate and sexuality induction both influenced by the temperature. This could also be the reason for the counter effect of the temperature at the DMA in IL or SI models. As the temperature value is on the other side of the unimodal shape relationship, it shows an opposite effect. It is important to mention that the temperature 
at the DMA is different among the blooms studied and remains to be elucidated. A reason could be the existence of different growth rate adaptations to temperature depending on the strain, as seen in Asterionella formosa (Gsell et al., 2012).

New field surveys should be conducted in order to determine whether this is one of the mechanisms driving the shape of blooms. They should determine the sexual transitions between increasing and decreasing phases taking into account the temperature values to test whether this variable drives the equilibrium between both processes. Also it would be interesting to determine whether the threshold temperature responsible for the equilibrium between sexuality induction and growth rate is site-adapted, strain-dependent or even related to excystment. This would explain the importance of the temperature at the DBS in determining the IL and the SI, as it would be linked to the characteristics of the population excysted and responsible for developing the bloom.

\section{Bloom termination}

The dissipation of blooms may be the result of several processes. The carrying capacity of the ecosystem is one of the causes of bloom termination. The nutrient limitation may be due to competition with other phytoplankton species (Chambouvet et al., 2008; Guisande et al., 2002; Ignatiades et al., 2007; Laanaia et al., 2013; Labry et al., 2008) as highlighted by Sourisseau et al. (2017) in Brest Bay; as well as to the lower nutrient supply from rivers (Maguer et al., 2004).

Predation (Calbet et al., 2003) or parasitism (Chambouvet et al., 2008) may also be invoked although they are not addressed here due to a lack of data. Calbet et al. (2003) suggest grazing by microzooplancton may be important in controlling A. minutum blooms in Arenys de Mar harbour but predators not previously exposed to A. minutum cells were used in the experiments, which is known to alter feeding behaviour (Da Costa and Fernandez, 2002, Guisande et al., 2002). In the same study, mesozooplankton is experimentally discarded to 
have an effect on A. minutum blooms. Probert (1999) conclude grazing unlikely to substantially contribute to the decline of A. minutum blooms surveyed in the Penzé and Abers regions. In that study the tintinnid Fabella ehrenbergii apparently did not react within the period of bloom meaning that the relative grazing impact was lowest at the time of the peaks in A. minutum population density (Probert 1999). In other studies, however, the tintinnid Fabella spp. contribute to the bloom termination of other Alexandrium species (Sorokin et al., 1996, Jeong et al., 2010).

The sexuality induction is another process responsible for bloom termination in Alexandrium species. Its importance is variable depending on the study. Some authors maintain that it is not the main factor (Estrada et al., 2010; Garcés, 2004) and others suggest that a high percentage of the vegetative cells undergo sexual reproduction and mainly contribute to the finalisation of the bloom (Anderson, 1998; Brosnahan et al., 2015; Probert, 1999; Velo-Suárez et al., 2013). As described before, this hypothesis agrees with the temperature influences on the IL parameter. Similarly, the relationship seen between temperature and DL or SD could also be related with the sexuality induction process. Probert (1999) also suggest that nutrient limitation induces sexual reproduction although others claimed that sexual induction is also seen when no limitations are observed (Figueroa et al., 2011; Garcés, 2004).

\subsection{Toxicity in A. minutum blooms}

Typically, the study of the toxin production and its dynamics were carried out in controlled culture experiments. In the present study, the toxicity data used were from the shellfish toxin content. Therefore, the processes involved in their analysis comprise (1) the PSP production by A. minutum, (2) its transfer mechanisms to shellfish and (3) its kinetics of accumulation and depuration in the shellfish.

The model developed here linked shellfish toxin content with A. minutum maximum abundance. Previous investigations have shown the increasing cellular toxin content toward 
the end of the growth phase or in the early stationary phase of A. minutum (Grzebyk et al., 2003; Touzet et al., 2008). Therefore, maximum toxicity in shellfish will coincide with the period of maximum cell concentration in the water column and maximum concentration of toxins within the cells. In the bloom measured in Pointe du Château in 2014 (Suppl. figure 7C) the maximum toxicity was reached before the peak, but it was already the end of the exponential phase and during the stationary phase of the bloom.

According to culture experiments, high $\mathrm{N}: \mathrm{P}$ ratios and low concentration of phosphate also enhance the toxin cellular content (Guisande et al., 2002; Lim et al., 2010; among others). The positive influence of the river flow during the MA in the model of the shellfish toxicity could be a proxy for the nutrient modulation of the toxin production described. River flows are the main source of nutrients in the coastal ecosystems, as seen for example in Brest Bay (Tréguer et al., 2014); and the season with the decreasing tendency in the flow rates coincides with the period of the bloom MA. Consequently, when bloom nutrient demand is higher, nutrient supply may decrease. In addition, Brittany estuaries usually present $\mathrm{N}: \mathrm{P}$ ratios ranging from 65 in summer to >300 in winter (Guillaud and Bouriel, 2007; Maguer et al., 2004) that can be generalised for all the French English Channel - Atlantic estuaries (Lefebvre et al., 2011; Romero et al., 2013). Therefore, not only nutrient concentration decrease but also N:P ratio is high during the MA of the bloom.

Other factors may be evocated to modulate toxin production but they are not shown by this analysis. Regarding salinity, a decrease in this variable also increases toxin production in some studies (Grzebyk et al., 2003; Hwang and Lu, 2000), but an experiment conducted with an A. minutum strain in Morlaix Bay showed that toxin production is stable for salinities between 30 and 37 (Grzebyk et al., 2003), a range similar to salinity values of our study. Finally, Lim et al. (2006) show that high temperatures also enhance toxin production in $A$. minutum. Nevertheless, this effect may be absent or masked by others in the data analysed. 
Toxicity in the shellfish will increase as the flux of toxic cells into its surroundings is enhanced. Therefore, processes like currents (generated by tide or rover flow) that lead to cells transport to the shellfish areas will enhance shellfish toxicity (Cugier and Le Hir, 2002; Raine, 2014). This is nevertheless a local effect.

Differences between the rates of PSP toxin accumulation and depuration can reach up to 100fold depending on the shellfish species analysed. Moreover, the lag time observed between the maximum density of toxic phytoplankton and the maximum shellfish toxicities is also a function of the shellfish analysed (Bricelj and Shumway, 1998 and references therein). In our study, these characteristics do not seem to mask the relationship found here between the shellfish toxicity and the A. minutum abundance. Nevertheless, the relatively low accuracy achieved by this model would be enhanced using the same shellfish species.

\section{Conclusions}

This study provides the first detailed description of the A. minutum blooms in the French English Channel - Atlantic coast using a comprehensive data set covering more than 25 years. The phenology of A. minutum blooms and its population dynamic were linked to environmental characteristics. Their effect on the species could be global, such as temperature; or global but with local characteristics that define the thresholds, as river flow. In addition, environmental variables may influence species in two different ways. River flow is a nutrient source favouring growth, but also promotes a population dilution effect; and temperature increase growth rate but also sexual induction. The final overall influence will depend on the magnitude of the variable. Therefore, in global studies local characteristics may also be taken into consideration because they define which, and how, these characteristics mainly influence the bloom events.

In addition, toxicity was also studied highlighting the link with the bloom maximum and the river flow. 
This study highlights the importance of the monitoring programs to understand the phytoplankton dynamics and their relation with the ecosystem, particularly for HABs. They should include direct measurements instead of using proxies like nutrient concentration or $A$. minutum life cycle. The results obtained provide useful information for risk management and can help to improve the monitoring surveillance strategy. Direct practical implications include the special attention to A. minutum events in relation with the temperature in the Bay of Brest or focus more efforts on the key phases of the bloom dynamics.

\section{Acknowledgements}

The authors thank the REPHY and SBR monitoring networks for providing phytoplankton and environmental data and all the members involved, especially to Elisabeth Nezan for providing expertise support. We also thank MétéoFrance, SHOM and CDOCO for providing meteorological, tidal and river flow data, respectively. Data were also successively collected in the framework of the following projects: FINAL, VELYGER, PARALEX and DAOULEX. The authors also wish to thank Francis Gohin and Philippe Bryère for providing satellite data and Pierre Bodenes for his help in figure 3 designing.

Funding: This work was supported by the Agence de l'Eau Loire Bretagne (AELB) in the frame of the project PHYTORISK. Carles Guallar was funded by AELB and IFREMER.

\section{References}

Abdenadher, M., Hamza, A., Fekih, W., Hannachi, I., Zouari Bellaaj, A., Bradai, M.N., Aleya, L., 2012. Factors determining the dynamics of toxic blooms of Alexandrium minutum during a 10-year study along the shallow southwestern Mediterranean coasts. Estuar. Coast. Shelf Sci. 106, 102-111. doi:10.1016/j.ecss.2012.04.029

Anderson, D.M., 1998. Physiology and bloom dynamics of toxic Alexandrium species, with emphasis on life cycle transitions, physiological ecology of harmful algal blooms. NATO 
ASI Series Vol. G41. Springer-Verlag, Berlin, Heidelberg.

Anderson, D.M., Alpermann, T.J., Cembella, A.D., Collos, Y., Masseret, E., Montresor, M., 2012. The globally distributed genus Alexandrium: Multifaceted roles in marine ecosystems and impacts on human health. Harmful Algae 14, 10-35. doi:10.1016/j.hal.2011.10.012

Anderson, D.M., Keafer, B.A., Geyer, W.R., Signell, R.P., Loder, T.C., 2005. Toxic Alexandrium blooms in the western Gulf of Maine: The plume advection hypothesis revisited. Limnol. Oceanogr. 50, 328-345. doi:10.4319/lo.2005.50.1.0328

Anderson, D.M., Kulis, D.M., Binder, B.J., 1984. Sexuality and cyst formation in the dinoflagellate Gonyaulax tamarensis: cyst yield in batch cultures. J. Phycol. 20, 418425. doi:10.1111/j.0022-3646.1984.00418.x

Ballabrera-Poy, J., Murtugudde, R.G., Christian, J.R., Busalacchi, A.J., 2003. Signal-to-noise ratios of observed monthly tropical ocean color. Geophys. Res. Lett. 30, n/a-n/a. doi:10.1029/2003GL016995

Behrenfeld, M.J., Doney, S.C., Lima, I., Boss, E.S., Siegel, D.A., 2013. Annual cycles of ecological disturbance and recovery underlying the subarctic Atlantic spring plankton bloom. Global Biogeochem. Cycles 27, 526-540. doi:10.1002/2013GB004681

Beliaeff, B., Gros, P., Belin, C., Raffin, B., Gailhard, I., Durbec, J.P., 2001. "Phytoplankton events" in French coastal waters during 1987-1997. Oceanol. Acta 24, 425-433. doi:10.1016/S0399-1784(01)01156-2

Bravo, I., Fraga, S., Figueroa, R.I., Pazos, Y., Massanet, A., Ramilo, I., 2010. Bloom dynamics and life cycle strategies of two toxic dinoflagellates in a coastal upwelling system (NW Iberian Peninsula). Deep. Res. Part II Top. Stud. Oceanogr. 57, 222-234. doi:10.1016/j.dsr2.2009.09.004

Bravo, I., Vila, M., Masó, M., Figueroa, R.I., Ramilo, I., 2008. Alexandrium catenella and 
Alexandrium minutum blooms in the Mediterranean Sea: Toward the identification of ecological niches. Harmful Algae 7, 515-522. doi:10.1016/j.hal.2007.11.005

Bricelj, V.M., Shumway, S.E., 1998. Paralytic shellfish toxins in bivalve molluscs: occurrence, transfer kinetics, and biotransformation. Rev. Fish. Sci. 6, 315-383. doi:10.1080/10641269891314294

Brosnahan, M.L., Velo-Suárez, L., Ralston, D.K., Fox, S.E., Sehein, T.R., Shalapyonok, A., Sosik, H.M., Olson, R.J., Anderson, D.M., 2015. Rapid growth and concerted sexual transitions by a bloom of the harmful dinoflagellate Alexandrium fundyense (Dinophyceae). Limnol. Oceanogr. 60, 2059-2078. doi:10.1002/lno.10155

Calbet, A., Vaqué, D., Felipe, J., Vila, M., Sala, M.M., Alcaraz, M., Estrada, M., 2003. Relative grazing impact of microzooplankton and mesozooplankton on a bloom of the toxic dinoflagellate Alexandrium minutum. Mar. Ecol. Prog. Ser. 259, 303-309. doi:10.3354/meps 259303

Cembella, A.D., Therriault, J.C., Béland, P., 1988. Toxicity of cultured isolates and natural populations of Protogonyaulax tamarensis from the St. Lawrence estuary. J. Shellfish Res. 7, 611-621.

Chambouvet, A., Morin, P., Marie, D., Guillou, L., 2008. Control of toxic marine dinoflagellate blooms by serial parasitic killers. Science (80-. ). 322, 1254-1257. doi:10.1126/science.1164387

Chang, F.H., McClean, M., 1997. Growth responses of Alexandrium minutum (Dinophyceae) as a function of three different nitrogen sources and irradiance. New Zeal. J. Mar. Freshw. Res. 31, 1-7. doi:10.1080/00288330.1997.9516740

Chapelle, A., Le Gac, M., Labry, C., Siano, R., Quere, J., Caradec, F., Le Bec, C., Nezan, E., Doner, A., Gouriou, J., 2015. The Bay of Brest (France), a new risky site for toxic Alexandrium minutum blooms and PSP shellfish contamination. Harmful Algae News 
$51,4-5$.

Cole, H., Henson, S.A., Martin, A., Yool, A., 2012. Mind the gap: The impact of missing data on the calculation of phytoplankton phenology metrics. J. Geophys. Res. Ocean. 117, 29. doi:10.1029/2012JC008249

Cosgrove, S., 2014. Monitoring methods and bloom dynamic studies of the toxic dinoflagellate genus Alexandrium. National University of Ireland Galway.

Cosgrove, S., Ní Rathaille, A., Raine, R., 2014. The influence of bloom intensity on the encystment rate and persistence of Alexandrium minutum in Cork Harbor, Ireland. Harmful Algae 31, 114-124. doi:10.1016/j.hal.2013.10.015

Cugier, P., Le Hir, P., 2002. Development of a 3D hydrodynamic model for coastal ecosystem modelling. Application to the plume of the Seine River (France). Estuar. Coast. Shelf Sci. 55, 673-695.

Cusack, C., Mouriño, H., Moita, M.T., Silke, J., 2015. Modelling Pseudo-nitzschia events off southwest Ireland. J. Sea Res. 105, 30-41. doi:10.1016/j.seares.2015.06.012

Da Costa, R.M., Fernández, F., 2002. Feeding and survival rates of the copepods Euterpina acutifrons Dana and Acartia grani Sars on the dinoflagellates Alexandrium minutum Balech and Gyrodinium corsicum Paulmier and the Chryptophyta Rhodomonas baltica Karsten. J. Exp. Mar. Biol. Ecol. 273, 141-142. doi: 10.1016/S0022-0981(02)00132-6

Delgado, M., Estrada, M., Camp, J., Fernandez, J. V., Santmarti, M., Lleti, C., 1990.

Development of a toxic Alexandrium minutum Halim (Dinophyceae) bloom in the harbour of Sant Carles de la Ràpita (Ebro Delta, northwestern Mediterranean). Sci. Mar. $54,1-7$.

Dia, A., Guillou, L., Mauger, S., Bigeard, E., Marie, D., Valero, M., Destombe, C., 2014. Spatiotemporal changes in the genetic diversity of harmful algal blooms caused by the toxic dinoflagellate Alexandrium minutum. Mol. Ecol. 23, 549-560. 
doi:10.1111/mec.12617

Edwards, M., Richardson, A.J., 2004. Impact of climate change on marine pelagic phenology and trophic mismatch. Nature 430, 881-884. doi:10.1038/nature02808

Erard-Le Denn, E., 1997. Alexandrium minutum, in: Berland B. \& Lassus P. (Ed.), Efflorescences toxiques des eaux côtieres françaises: ecologie, ecophysiologie, toxicologie. IFREMER, Brest, pp. 53-65.

Estrada, M., Solé, J., Anglès, S., Garcés, E., 2010. The role of resting cysts in Alexandrium minutum population dynamics. Deep. Res. Part II Top. Stud. Oceanogr. 57, 308-321. doi:10.1016/j.dsr2.2009.09.007

Fan Jianqing, L.R., 2001. Variable Selection via Nonconcave Penalized. J. Am. Stat. Assoc. $96,1348-1360$.

Ferreira, A.S., Visser, A.W., MacKenzie, B.R., Payne, M.R., 2014. Accuracy and precision in the calculation of phenology metrics. J. Geophys. Res. Ocean. 119, 8438-8453. doi:10.1002/2014JC010323

Figueroa, R.I., Garcés, E., Bravo, I., 2007. Comparative study of the life cycles of Alexandrium tamutum and Alexandrium minutum (Gonyaulacales, Dinophyceae) in culture. J. Phycol. 43, 1039-1053. doi:10.1111/j.1529-8817.2007.00393.x

Figueroa, R.I., Vázquez, J.A., Massanet, A., Murado, M.A., Bravo, I., 2011. Interactive effects of salinity and temperature on planozygote and cyst formation of Alexandrium minutum (Dinophyceae) in culture. J. Phycol. 47, 13-24. doi:10.1111/j.15298817.2010.00937.x

Flater, D., n.d. XTide [WWW Document]. URL http://www.flaterco.com/xtide/ (accessed 4.14.16).

Garcés, E., 2004. Relationship between vegetative cells and cyst production during Alexandrium minutum bloom in Arenys de Mar harbour (NW Mediterranean). J. 
Plankton Res. 26, 637-645. doi:10.1093/plankt/fbh065

Garcés, E., Delgado, M., Vila, M., Camp, J., 1998. An Alexandrium minutum bloom: in situ growth or accumulation?, in: Reguera, B., Blanco, J., Fernández, M.L., Wyatt, T. (Eds.), Proceedings of the eight international conference on harmful algae. Xunta de Galicia and Intergovernmental Oceanographic Commission of UNESCO, Vigo, pp. 167-170.

Giacobbe, M.G., Oliva, F.D., Maimone, G., 1996. Environmental factors and seasonal occurrence of the dinoflagellate Alexandrium minutum, a PSP potential producer, in a Mediterranean lagoon. Estuar. Coast. Shelf Sci. 42, 539-549. doi:10.1006/ecss.1996.0035

González Vilas, L., Spyrakos, E., Torres Palenzuela, J.M., Pazos, Y., 2014. Support vector machine-based method for predicting Pseudo-nitzschia spp. blooms in coastal waters (Galician rias, NW Spain). Prog. Oceanogr. 124, 66-77. doi:10.1016/j.pocean.2014.03.003

Greve, W., Prinage, S., Zidowitz, H., Nast, J., Reiners, F., 2005. On the phenology of North Sea ichthyoplankton. ICES J. Mar. Sci. 62, 1216-1223. doi:10.1016/j.icesjms.2005.03.011

Grzebyk, D., Béchemin, C., Ward, C.J., Vérité, C., Codd, G.A., Maestrini, S.Y., 2003. Effects of salinity and two coastal waters on the growth and toxin content of the dinoflagellate Alexandrium minutum. J. Plankton Res. 25, 1185-1199. doi:10.1093/plankt/fbg088

Gsell, A.S., de Senerpont Domis, L.N., Przytulska-Bartosiewicz, A., Mooij, W.M., van Donk, E., Ibelings, B.W., 2012. Genotype-by-temperature interactions may help to maintain clonal diversity in Asterionella formosa (Bacillariophyceae). J. Phycol. 48, 1197-1208. doi:10.1111/j.1529-8817.2012.01205.x

Guallar, C., Chapelle, A., Bacher, C., 2015. Effet des changements environnementaux sur les communautés phytoplanctoniques et évaluation des risques d'efflorescences d'algues 
toxiques (PhytoRisk) Livrable : Données environnementales utilisées et modèles de la phénologie des espèces de phytoplancton. http://archimer.ifremer.fr/doc/00278/38878/.

Guallar, C., Delgado, M., Diogène, J., Fernández-Tejedor, M., 2016. Artificial neural network approach to population dynamics of harmful algal blooms in Alfacs Bay (NW Mediterranean): Case studies of Karlodinium and Pseudo-nitzschia. Ecol. Modell. 338, 37-50. doi:10.1016/j.ecolmodel.2016.07.009

Guillaud, J.-F., Bouriel, L., 2007. Relation concentration-débit et évolution temporelle du nitrate dans 25 rivières de la région Bretagne (France). Rev. des Sci. l'eau 20, 213-226. doi:10.7202/015814ar

Guisande, C., Frangópulos, M., Maneiro, I., Vergara, A.R., Riveiro, I., 2002. Ecological advantages of toxin production by the dinoflagellate Alexandrium minutum under phosphorus limitation. Mar. Ecol. Prog. Ser. 225, 169-176. doi:10.3354/meps225169

Hallegraeff, G.M., 2003. Harmful algal blooms: a global overview. In: Hallegraeff, G.M., Anderson, D.M., Cembella, A.D. (Eds.), Manual on Harmful Marine Microalgae. UNESCO, Paris, pp. 25-49.

Hernández-Fariñas, T., Bacher, C., Soudant, D., Belin, C., Barillé, L., 2015. Assessing phytoplankton realized niches using a French national phytoplankton monitoring network. Estuar. Coast. Shelf Sci. 159, 15-27. doi:10.1016/j.ecss.2015.03.010

Hernández-Fariñas, T., Soudant, D., Barillé, L., Belin, C., Lefebvre, A., Bacher, C., 2014. Temporal changes in the phytoplankton community along the French coast of the eastern English Channel and the southern Bight of the North Sea. ICES J. Mar. Sci. 71, 821833.

Husson, B., Hernández-Fariñas, T., Le Gendre, R., Schapira, M., Chapelle, A., 2016. Two decades of Pseudo-nitzschia spp. blooms and king scallop (Pecten maximus) contamination by domoic acid along the French Atlantic and English Channel coasts: 
Seasonal dynamics, spatial heterogeneity and interannual variability. Harmful Algae 51, 26-39. doi:10.1016/j.hal.2015.10.017

Hwang, D.F., Lu, Y.H., 2000. Influence of environmental and nutritional factors on growth, toxicity, and toxin profile of dinoflagellate Alexandrium minutum. Toxicon 38, 14911503. doi:10.1016/S0041-0101(00)00080-5

Hydes, D.J., Aoyama, M., Aminot, A., Bakker, K., Becker, S., Coverly, S., Daniel, A., Dickson, A.G., Grosso, O., Kerouel, R., van Oojen, J., Sato, K., Tanhua, T., Wood-ward, E.M.S., Zhang, J.Z., 2010. Determination of dissolved nutrients (N, P, Si) in seawater with high precision and inter-comparability using gas-segmented continuous flow analysers. In: Hood, E.M., Sabine, C.L., Sloyan, B.M. (Eds.), The GO-SHIP Repeat Hydrography Manual: A collection of Expert Reports and Guidelines. IOCCP Report No. 14, ICPO Publication Series No. 134, pp. 1-87.

Ignatiades, L., Gotsis-Skretas, O., Metaxatos, A., 2007. Field and culture studies on the ecophysiology of the toxic dinoflagellate Alexandrium minutum (Halim) present in Greek coastal waters. Harmful Algae 6, 153-165. doi:10.1016/j.hal.2006.04.002

Irwin, A.J., Nelles, A.M., Finkel, Z. V., 2012. Phytoplankton niches estimated from field data. Limnol. Oceanogr. 57, 787-797. doi:10.4319/lo.2012.57.3.0787

Jeong, H.J., Yoo, Y.D., Kim, J.S., Seong, K.A., Kang, N.S., Kim, T.H., 2010. Growth, feeding and ecological roles of the mixotrophic and heterotrophic dinoflagellates in marine planktonic food webs. Ocean Sci. J. 45, 65-91. doi: 10.1007/s12601-010-0007-2 Ji, R., Edwards, M., Mackas, D.L., Runge, J. a, Thomas, A.C., 2010. Marine plankton phenology and life history in a changing climate: current research and future directions. J. Plankton Res. 32, 1355-1368. doi:10.1093/plankt/fbq062

Klouch, K.Z., Schmidt, S., Andrieux-Loyer, F., Le Gac, M., Hervio-Heath, D., Qui-Minet, Z.N., Quéré, J., Bigeard, E., Guillou, L., Siano, R., 2016. Historical records from dated 
sediment cores reveal the multidecadal dynamic of the toxic dinoflagellate Alexandrium minutum in the Bay of Brest (France). FEMS Microbiol. Ecol. 92, fiw101. doi:10.1093/femsec/fiw101

Laabir, M., Jauzein, C., Genovesi, B., Masseret, E., Grzebyk, D., Cecchi, P., Vaquer, A., Perrin, Y., Collos, Y., 2011. Influence of temperature, salinity and irradiance on the growth and cell yield of the harmful red tide dinoflagellate Alexandrium catenella colonizing Mediterranean waters. J. Plankton Res. 33, 1550-1563. doi:10.1093/plankt/fbr050

Laabir, M., Collos, Y., Masseret, E., Grzebyk, D., Abadie, E., Savar, V., Sibat, M., Amzil, Z., 2013. Influence of environmental factors on the paralytic shellfish toxin content and profile of Alexandrium catenella (Dinophyceae) isolated from the Mediterranean Sea. Mar. Drugs 11, 1583-1601. doi:10.3390/md11051583

Laanaia, N., Vaquer, A., Fiandrino, A., Genovesi, B., Pastoureaud, A., Cecchi, P., Collos, Y., 2013. Wind and temperature controls on Alexandrium blooms (2000-2007) in Thau lagoon (Western Mediterranean). Harmful Algae 28, 31-36. doi:10.1016/j.hal.2013.05.016

Labib, W., Halim, Y., 1995. Diel vertical migration and toxicity of Alexandrium minutum Halim red tide, in Alexandria, Egypt. Mar. Life 5, 11-17.

Labry, C., Erard-Le Denn, E., Chapelle, A., Fauchot, J., Youenou, A., Crassous, M.P., Le Grand, J., Lorgeoux, B., 2008. Competition for phosphorus between two dinoflagellates: A toxic Alexandrium minutum and a non-toxic Heterocapsa triquetra. J. Exp. Mar. Bio. Ecol. 358, 124-135. doi:10.1016/j.jembe.2008.01.025

Lassus, P., Bardouil, M., 1988. Présence d'un Protogonyaulax sp. sur le littoral Atlantique Français pendant 1'hiver 1987. Cryptogam. Algol. 9, 273-278.

Le Borgne, P., Legendre, G., Marsouin, A., 2006a. Validation of the OSI SAF radiative 
fluxes, in: Proceedings of the 2006 EUMETSAT conference. Helsinki, pp. 12-16.

Le Borgne, P., Legendre, G., Marsouin, A., 2006b. Operational SST Retrieval From Msg / Seviri Data, in: Proceedings of the 2006 EUMETSAT conference. Helsinki, Finnland. Lefebvre, A., Guiselin, N., Barbet, F., Artigas, F.L., 2011. Long-term hydrological and phytoplankton monitoring (1992-2007) of three potentially eutrophic systems in the eastern English Channel and the Southern Bight of the North Sea. ICES J. Mar. Sci. 68, 2029-2043. doi:10.1093/icesjms/fsr149

Lim, P.-T., Leaw, C.-P., Usup, G., Kobiyama, A., Koike, K., Ogata, T., 2006. Effects of light and temperature on growth, nitrate uptake, and toxin production of two tropical dinoflagellates: Alexandrium tamiyavanichii and Alexandrium minutum (Dinophyceae). J. Phycol. 42, 786-799. doi:10.1111/j.1529-8817.2006.00249.x

Lim, P.T., Leaw, C.P., Kobiyama, A., Ogata, T., 2010. Growth and toxin production of tropical Alexandrium minutum Halim (Dinophyceae) under various nitrogen to phosphorus ratios. J. Appl. Phycol. 22, 203-210. doi:10.1007/s10811-009-9443-8

Maguer, J.-F., Wafar, M., Madec, C., Morin, P., Erard-Le Denn, E., 2004. Nitrogen and phosphorus requirements of an Alexandrium minutum bloom in the Penzé estuary, France. Limnol. Oceanogr. 49, 1108-1114. doi:10.4319/lo.2004.49.4.1108

Maritorena, S., Siegel, D.A., 2005. Consistent merging of satellite ocean color data sets using a bio-optical model. Remote Sens. Environ. 94, 429-440. doi:10.1016/j.rse.2004.08.014 McGillicuddy, D.J., Signell, R.P., Stock, C.A., Keafer, B.A., Keller, M.D., Hetland, R.D., Anderson, D.M., 2003. A mechanism for offshore initiation of harmful algal blooms in the coastal Gulf of Maine. J. Plankt. Res. 25, 1131-1138.

Mieruch, S., Freund, J.A., Feudel, U., Boersma, M., Janisch, S., Wiltshire, K.H., 2010. A new method of describing phytoplankton blooms: Examples from Helgoland Roads. J. Mar. Syst. 79, 36-43. doi:10.1016/j.jmarsys.2009.06.004 
Navarro, J.M., Muñoz, M.G., Contreras, A.M., 2006. Temperature as a factor regulating growth and toxin content in the dinoflagellate Alexandrium catenella. Harmful Algae 5, 762-769. doi:10.1016/j.hal.2006.04.001

Ní Rathaille, A., Raine, R., 2011. Seasonality in the excystment of Alexandrium minutum and Alexandrium tamarense in Irish coastal waters. Harmful Algae 10, 629-635. doi:10.1016/j.hal.2011.04.015

Parmesan, C., Yohe, G., 2003. A globally coherent fingerprint of climate change impacts across natural systems. Nature 421, 37-42. doi:10.1038/nature01286

Pitcher, G.C., Cembella, A.D., Joyce, L.B., Larsen, J., Probyn, T.A., Ruiz Sebastián, C., 2007. The dinoflagellate Alexandrium minutum in Cape Town harbour (South Africa): Bloom characteristics, phylogenetic analysis and toxin composition. Harmful Algae 6, 823-836. doi:10.1016/j.hal.2007.04.008

Probert, I.P., 1999. Sexual reproduction and ecophysiology of the marine dinoflagellate Alexandrium minutum Halim. University of Westminster, London.

Raine, R., 2014. A review of the biophysical interactions relevant to the promotion of HABs in stratified systems: The case study of Ireland. Deep Sea Res. Part II Top. Stud. Oceanogr. 101, 21-31. doi:10.1016/j.dsr2.2013.06.021

Ralston, D.K., Keafer, B.A., Brosnahan, M.L., Anderson, D.M., 2014. Temperature dependence of an estuarine harmful algal bloom: Resolving interannual variability in bloom dynamics using a degree-day approach. Limnol. Oceanogr. 59, 1112-1126. doi:10.4319/lo.2014.59.4.1112

Rolinski, S., Horn, H., Petzoldt, T., Paul, L., 2007. Identifying cardinal dates in phytoplankton time series to enable the analysis of long-term trends. Oecologia 153, 997-1008. doi:10.1007/s00442-007-0783-2

Romero, E., Garnier, J., Lassaletta, L., Billen, G., Le Gendre, R., Riou, P., Cugier, P., 2013. 
Large-scale patterns of river inputs in southwestern Europe: seasonal and interannual variations and potential eutrophication effects at the coastal zone. Biogeochemistry 113, 481-505. doi:10.1007/s10533-012-9778-0

Seity, Y., Brousseau, P., Malardel, S., Hello, G., Bénard, P., Bouttier, F., Lac, C., Masson, V., 2011. The AROME-France convective-scale operational model. Mon. Weather Rev. 139, 976-991. doi:10.1175/2010MWR3425.1

Smayda, T.J., 1997. What is a bloom? A commentary. Limnol. Oceanogr. 42, 1132-1136. doi:10.4319/lo.1997.42.5_part_2.1132

Sorokin, Y.I., Sorokin, P.Y., Ravagnan, G., 1996. On an extremely dense bloom of the dinoflagellate Alexandrium tamarense in lagoons of the Po river delta: Impact on the environment. J. Sea Res. 35, 251-255. doi: 10.1016/S1385-1101(96)90752-2

Sourisseau, M., Chapelle, A., Le Guennec, V., Le Gland, G., 2017. How competition for resources drive specific niches and community structure of phytoplankton by using a trait-based model. Frontiers in Marine Science 4(52), 1-14. doi: 10.3389/fmars.2017.00052

Team, R.C., 2015. R: A language and environment for statistical computing. Team, Rs., 2015. RStudio: Integrated Development for R.

Touzet, N., Franco, J.M., Raine, R., 2008. PSP toxin analysis and discrimination of the naturally co-occurring Alexandrium tamarense and A. minutum (Dinophyceae) in Cork Harbour, Ireland. Aquat. Microb. Ecol. 51, 285-299. doi:10.3354/ame01189

Trainer, V.L., Eberhart, B.T.L., Wekell, J.C., Adams, N.G., Hanson, L., Cox, F., Dowell, J., 2003. Paralytic shellfish toxins in Puget Sound, Washington State. J. Shellfish Res. 22, 213-223.

Tréguer, P., Goberville, E., Barrier, N., L’Helguen, S., Morin, P., Bozec, Y., Rimmelin- 
Maury, P., Czamanski, M., Grossteffan, E., Cariou, T., Répécaud, M., Quéméner, L., 2014. Large and local-scale influences on physical and chemical characteristics of coastal waters of Western Europe during winter. J. Mar. Syst. 139, 79-90. doi:10.1016/j.jmarsys.2014.05.019

Utermöhl, H., 1958. Zur Vervollkommnung der quantitativen phytoplankton-methodik. Mitt. Int. Ver. Theor. Angew. Limnol. 9, 1-38.

Velo-Suárez, L., Brosnahan, M.L., Anderson, D.M., McGillicuddy, D.J., 2013. A quantitative assessment of the role of the parasite Amoebophrya in the termination of Alexandrium fundyense blooms within a small coastal embayment. PLoS One 8, e81150. doi:10.1371/journal.pone.0081150

Verbesselt, J., Hyndman, R., Zeileis, A., Culvenor, D., 2010. Phenological change detection while accounting for abrupt and gradual trends in satellite image time series. Remote Sens. Environ. 114, 2970-2980. doi:10.1016/j.rse.2010.08.003

Vila, M., Giacobbe, M.G., Masó, M., Gangemi, E., Penna, A., Sampedro, N., Azzaro, F., Camp, J., Galluzzi, L., 2005. A comparative study on recurrent blooms of Alexandrium minutum in two Mediterranean coastal areas. Harmful Algae 4, 673-695. doi:10.1016/j.hal.2004.07.006

Walther, G., Post, E., Convey, P., Menzel, A., Parmesan, C., Beebee, T.J.C., Fromentin, J.M., Hoegh-Guldberg, O., Bairlein, F., 2002. Ecological responses to recent climate change. Nature 416, 389-395. doi:10.1038/416389a

Wells, M.L., Trainer, V.L., Smayda, T.J., Karlson, B.S.O., Trick, C.G., Kudela, R.M., Ishikawa, A., Bernard, S., Wulff, A., Anderson, D.M., Cochlan, W.P., 2015. Harmful algal blooms and climate change: Learning from the past and present to forecast the future. Harmful Algae 49, 68-93. doi:10.1016/j.hal.2015.07.009

Wiltshire, K.H., Malzahn, A.M., Wirtz, K., Greve, W., Janisch, S., Mangelsdorf, P., Manly, 
B.F.J., Boersma, M., 2008. Resilience of North Sea phytoplankton spring bloom dynamics: An analysis of long-term data at Helgoland Roads. Limnol. Oceanogr. 53, 1294-1302. doi:10.4319/lo.2008.53.4.1294

\section{Figures}

Figure 1. Representation of the phenology variables. DBS, Date of Bloom Start; $\mathrm{x}_{0}$, abundance at DBS; SI, Steepness Increase; IL, Increasing Length; BL, Bloom Length; MA, Maximum Abundance; DMA, Date of the Maximum Abundance; SD, Steepness Decrease; DL, Decreasing Length; DBE, Date of the Bloom End; and $\mathrm{x}_{\mathrm{e}}$, abundance at the DBE.

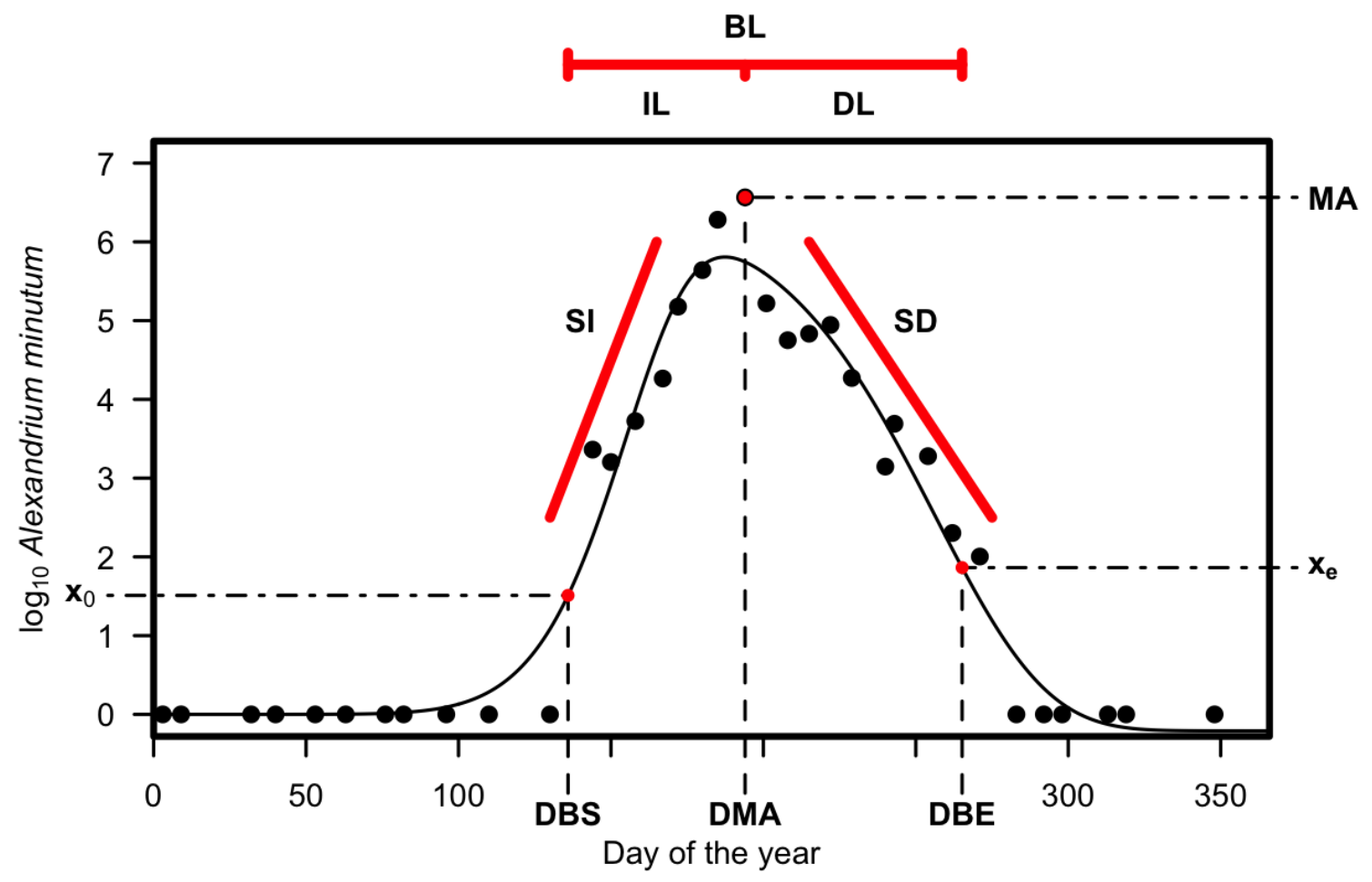


Figure 2. Scatter plot between a theoretical variable and fictitious $\log _{10}$ transformed abundances of $A$. minutum with the results of the threshold analysis. The horizontal lines represent the abundances where the threshold values are defined $\left(10^{2}, 10^{4}\right.$ and $10^{6}$ cells $\mathrm{L}^{-1}$, dashed, dash dotted and solid lines, respectively). The values annotated on the horizontal lines correspond to the validated thresholds. Vertical lines represent the validated thresholds with the same line type as A. minutum abundance thresholds. The grey area with shading lines (or coloured area in on-line version) highlights the variable range in which the threshold abundance of A. minutum is detected and the grey intensity and the inclination of the shading lines (or the colour in the on-line version) define the corresponding threshold category.

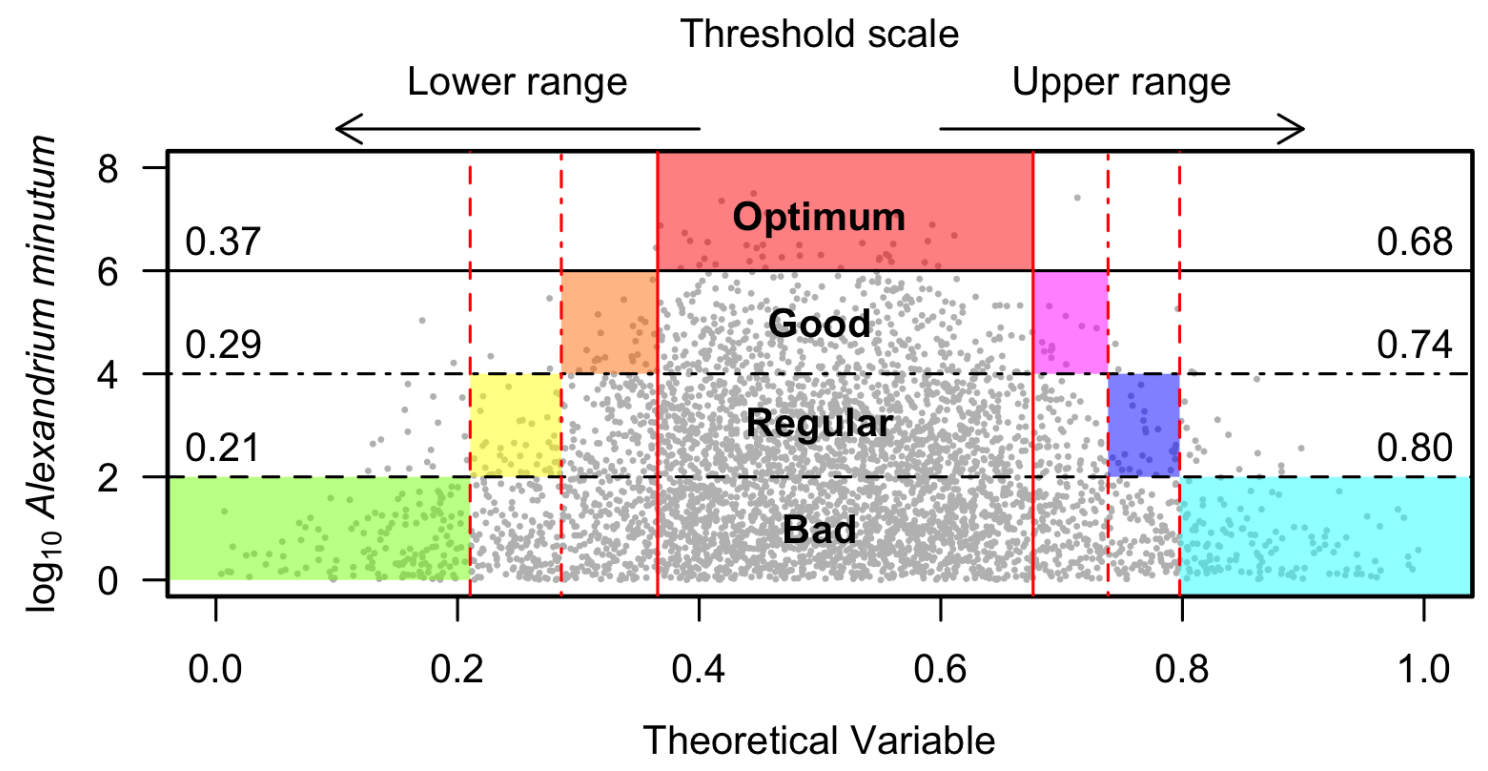


Figure 3. Regions and stations included in the phenology study of A. minutum.

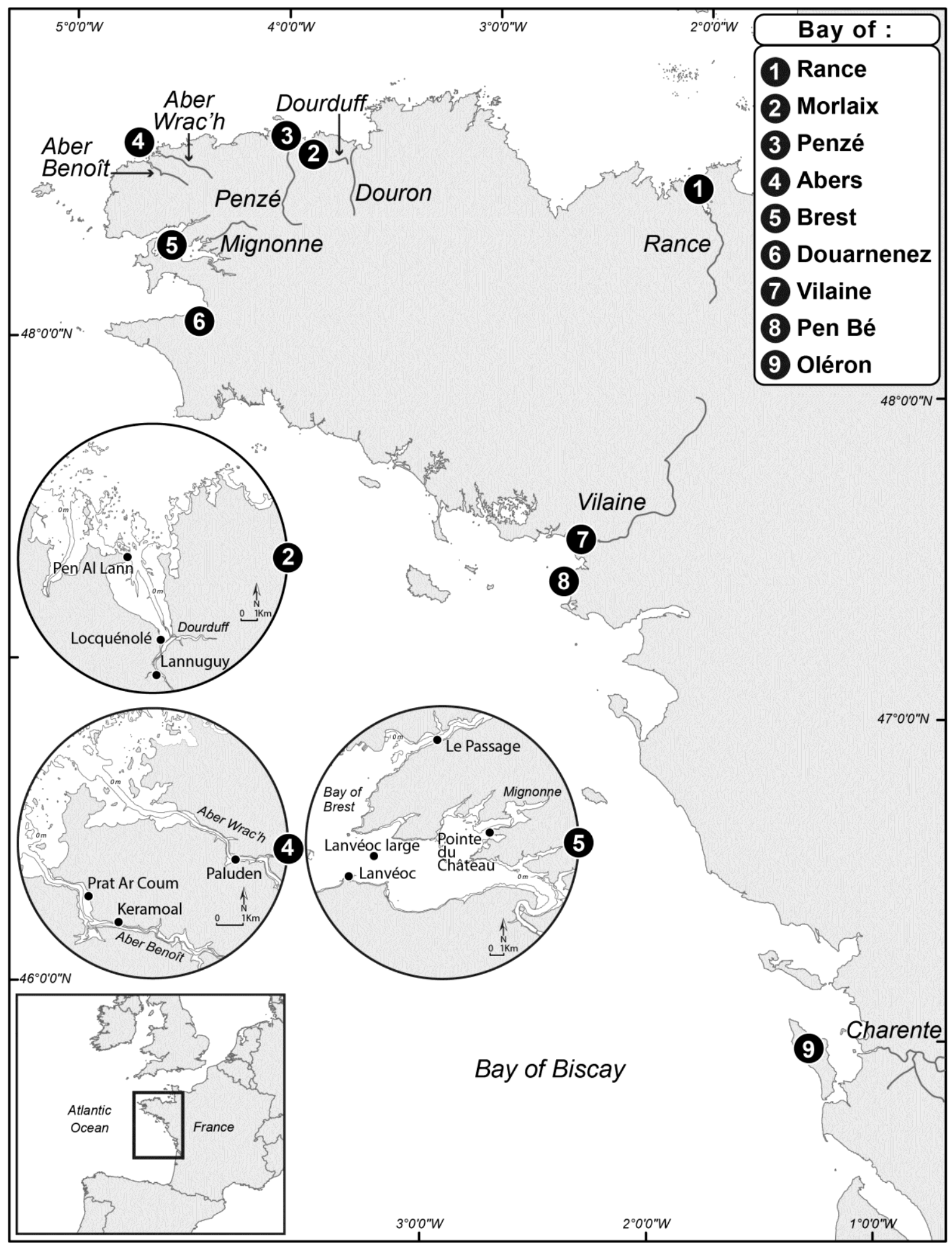


Figure 4. Seasonality of (A) irradiance, $(C)$ water temperature and (E) river flow for the nine regions studied, calculated from 1989 to 2014. Boxplot for (B) daily tidal range, (D) wind velocity, $(\mathrm{F})$ salinity, $(\mathrm{G})$ phosphate and $(\mathrm{H})$ nitrate plus nitrite for the same regions. In boxplot, horizontal bars represent the median (second quartile); the end boxes are the first and third quartile; and the dotted line is a measure of the statistical dispersion of the data, calculated as 1.58 times the interquartile distance. Points beyond dotted lines are possible outliers. In $(\mathrm{G})$ and $(\mathrm{H})$, outliers are not plotted and the width of the bars are proportional to the data available.
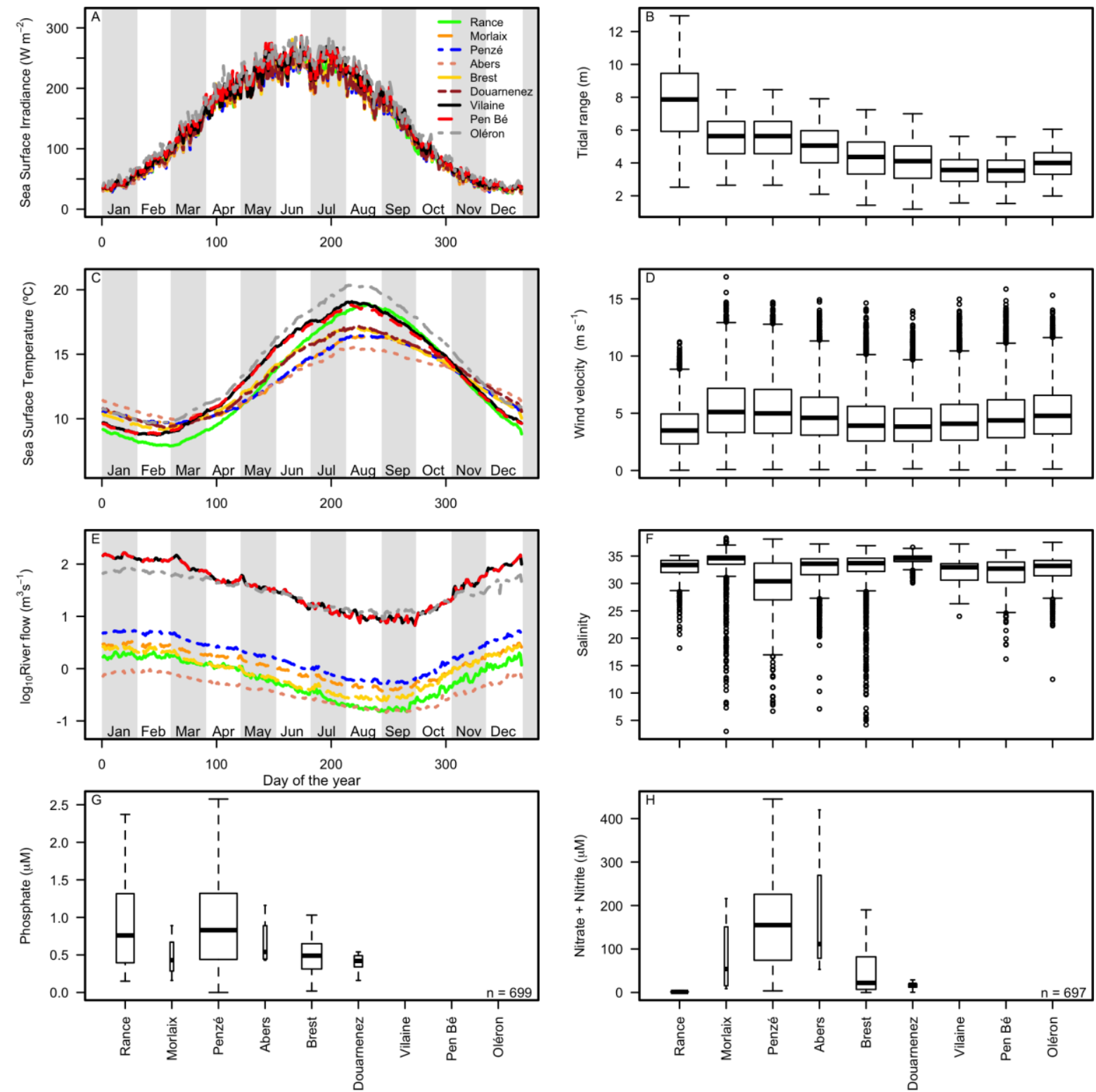
Figure 5. Summary of the phenology variables. In boxplot, horizontal bars represent the median (second quartile); the end boxes are the first and third quartile delimiting the middle half distribution of the variable; and the dotted line is a measure of the statistical dispersion of the data, calculated as 1.58 times the interquartile distance. Points beyond dotted lines are possible outliers. Acronyms: MA, Maximum Abundance; BL, Bloom Length; IL, Increasing Length; DL, Decreasing Length; DBS, Date of Bloom Start; DMA, Date of Maximum Abundance; DBE, Date of Bloom End; SI, Steepness Increase; SD, Steepness Decrease.
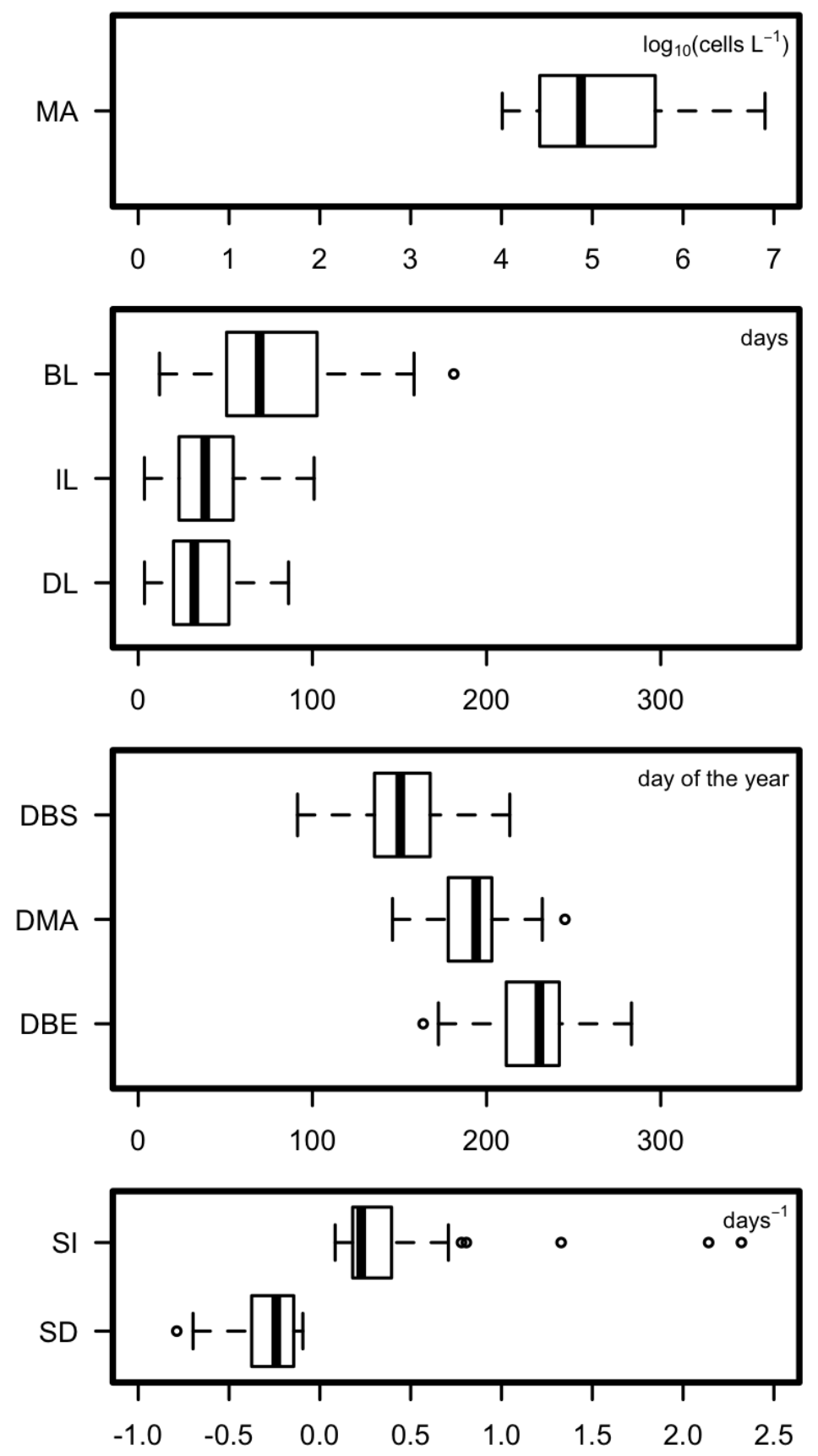
Figure 6. Model results for (A) Increasing Length, (B) Steepness Increase using weekly mean of the DBS instead of mean water temperature of the increasing phase of the bloom (see text), and (C) PSP toxicity.
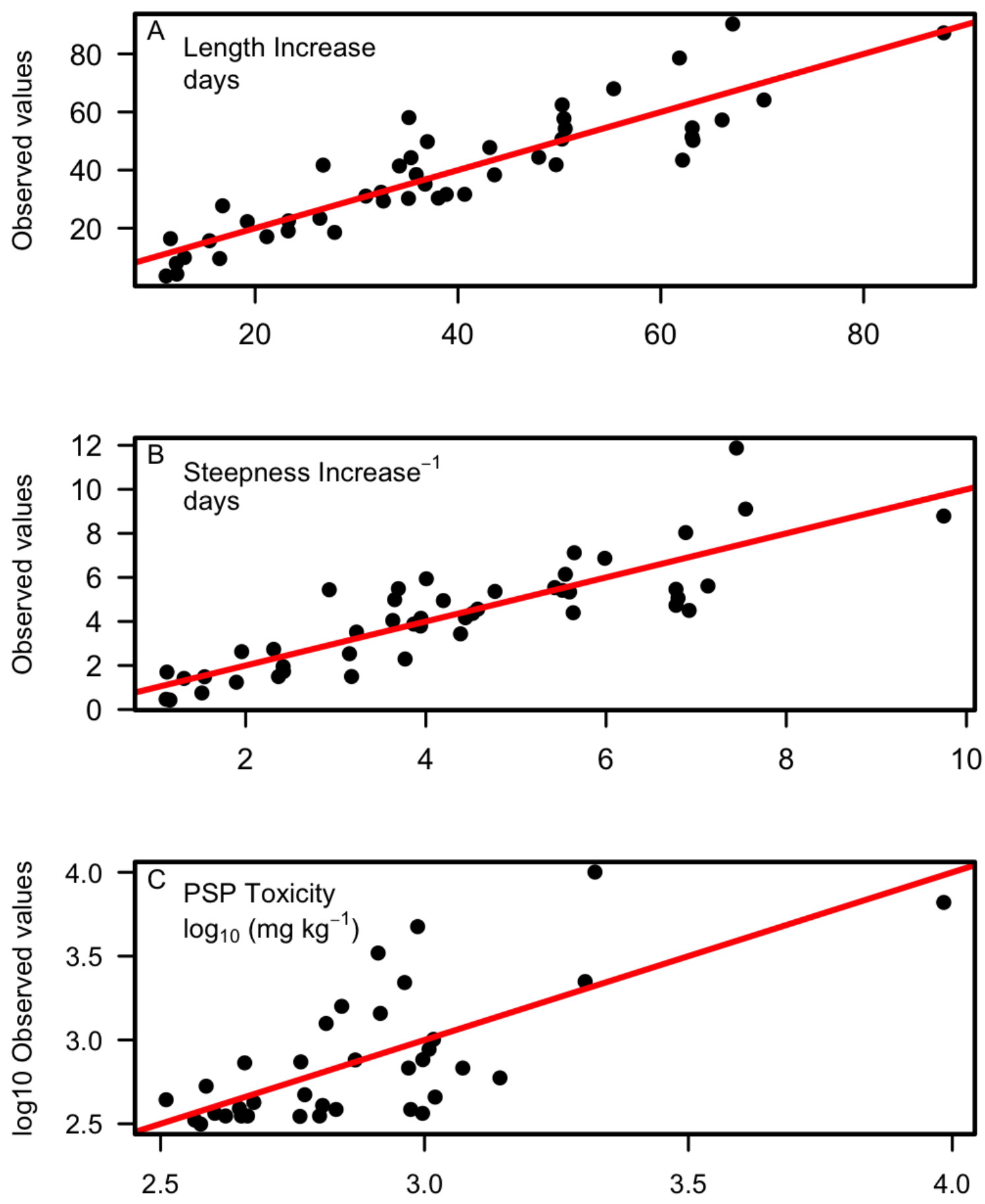

Fitted values 
Figure 7. Threshold values for (A) Temperature and (B) Tidal coefficient using the available data.
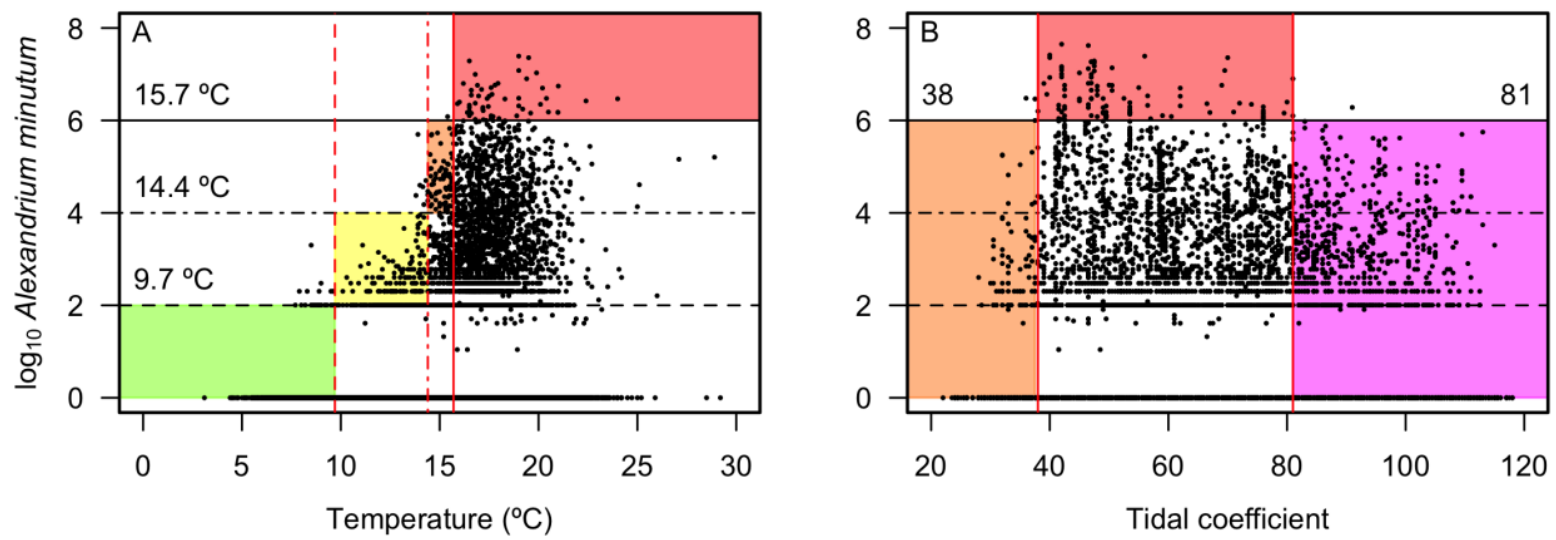

Figure 8. Threshold values for river flow using (A) Rance Estuary, (B) Morlaix Bay, (C)

Penzé Bay and (D) Abers region data.
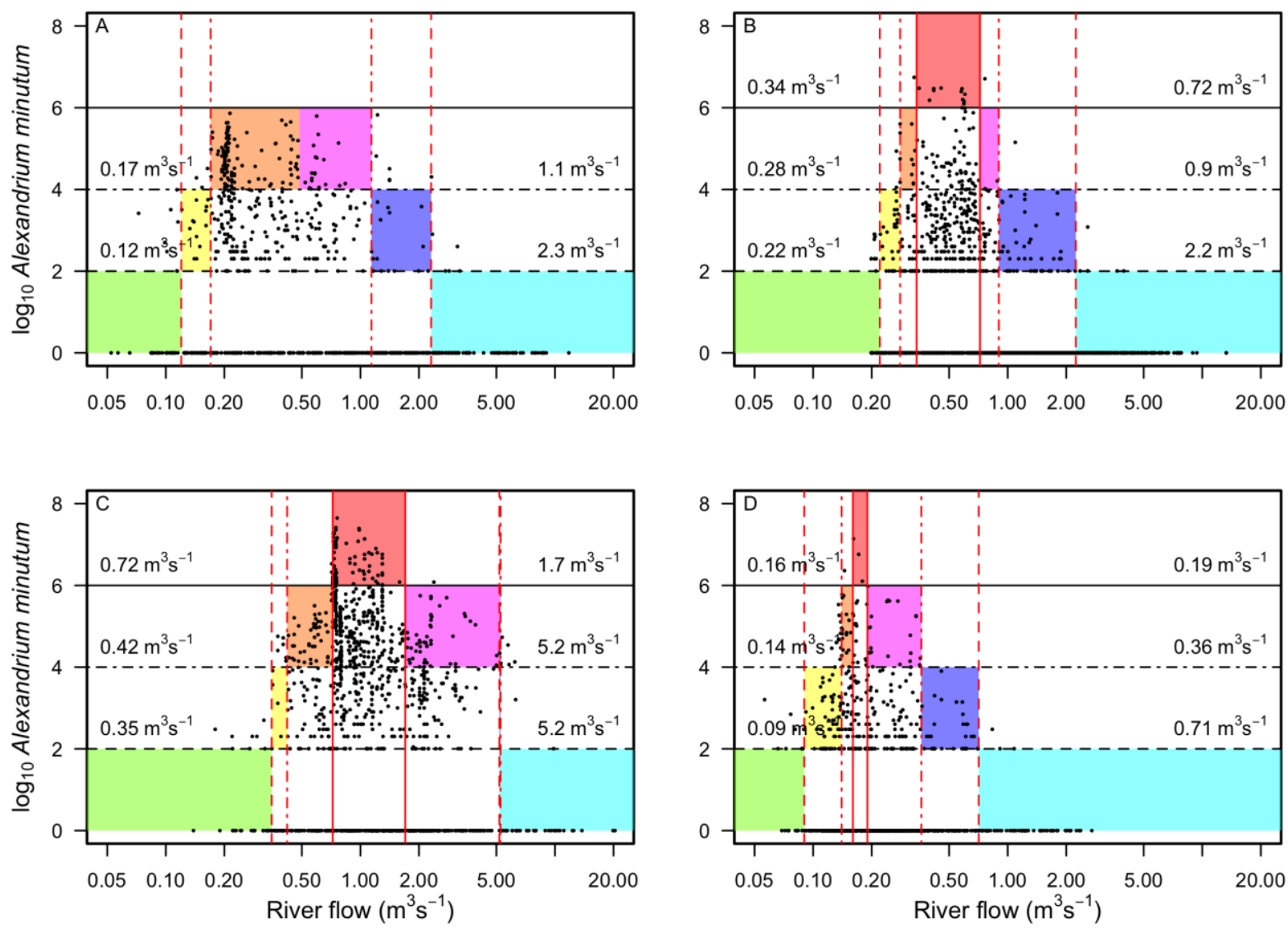
Figure 9. Representation of bloom, environmental variables evolution, phenology and threshold analysis in (A) 1989, (B) 1993 and (C) 1994 in Pen al Lann (Morlaix Bay). Grey scale with shading lines (or colour scale in the on-line version) represents environmental variable thresholds, grey scale represents environmental variable intensity and shaded rectangles represent PSP toxicity levels.

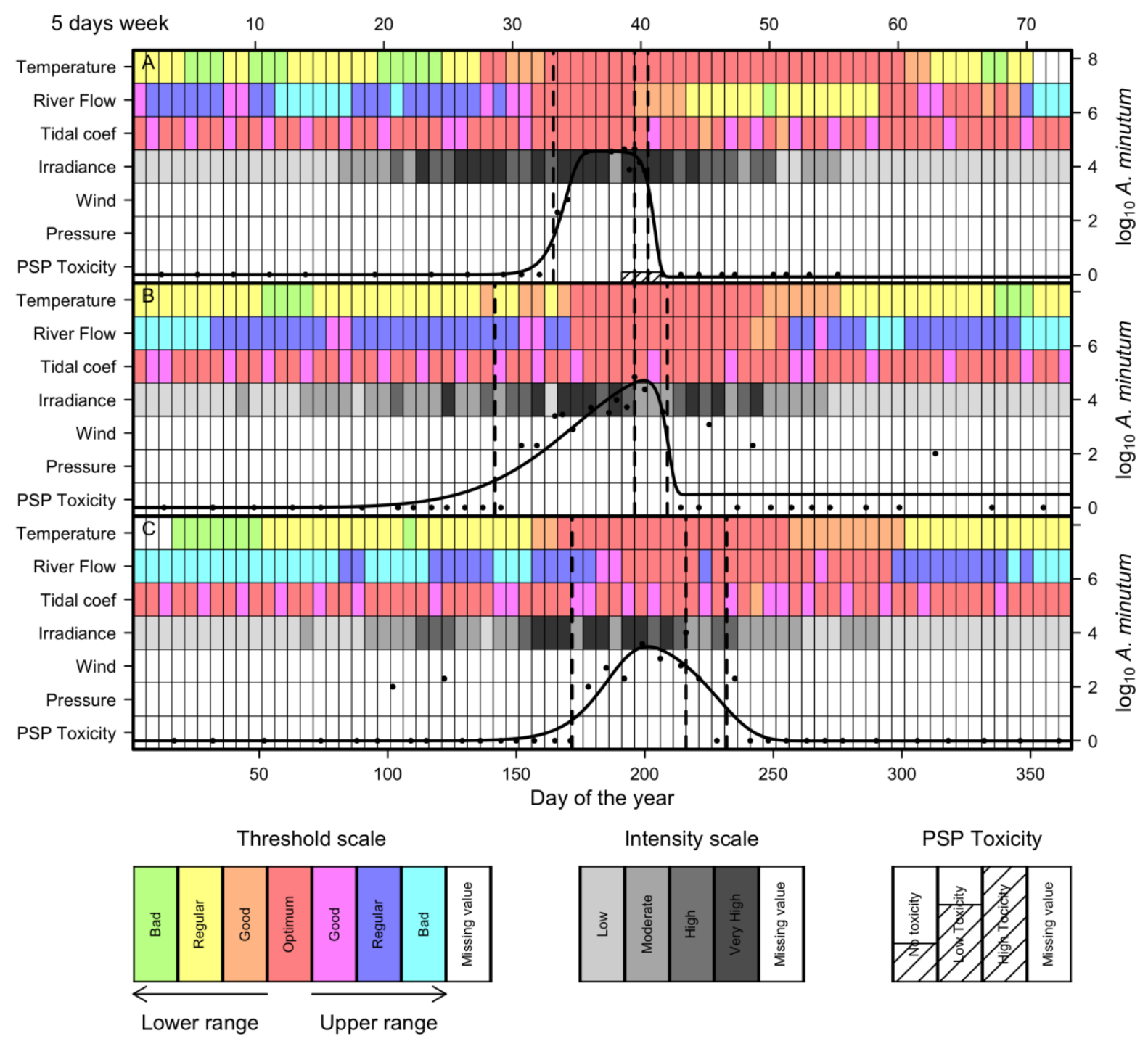




\section{Tables}

Table 1. Summary of the Increasing Length (IL) model.

\begin{tabular}{lccc} 
& Estimate & Std. error & p-value \\
\hline Intercept & 50.88 & 20.67 & 0.018 \\
SST weekly mean of the DBS & -11.56 & 0.96 & $<0.001$ \\
SST weekly mean of the DMA & 9.25 & 1.32 & $<0.001$ \\
Mean. std. $\log _{10}$ river flow 3days before DMA & -29.49 & 10.55 & 0.008
\end{tabular}

Table 2. Summary of the inverse of the Steepness Increase (SI) model.

\begin{tabular}{lccc} 
& Estimate & Std. error & p-value \\
\hline Intercept & 4.72 & 2.83 & 0.103 \\
SST weekly mean of the DBS & -1.23 & 0.13 & $<0.001$ \\
SST weekly mean of the DMA & 1.06 & 0.18 & $<0.001$ \\
Mean. std. $\log _{10}$ river flow 3days before DMA & -4.02 & 1.44 & 0.008
\end{tabular}

Table 3. Summary of the PSP toxin concentration model.

\begin{tabular}{lccc} 
& Estimate & Std. error & p-value \\
\hline Intercept & 1.59 & 0.35 & $<0.001$ \\
Log $_{10}$ transformed MA & 0.20 & 0.07 & 0.005 \\
Min. std. river flow 5days before DMA & 11.19 & 3.48 & 0.003
\end{tabular}




\section{Supplementary information}

Supplementary figure 1. Results of the fitted Weibull function for the 53 TS. Blue circles show the $\log _{10}$ transformed $A$. minutum abundances, black lines represent the fitted Weibull function and red points are the cardinal dates (Day of the Bloom Start DBS, Day of the Maximum Abundance - DMA, and Day of the Bloom End - DBE).

Cross diamonds mark TS in which the decreasing phase parameters were discarded due to insufficient data.

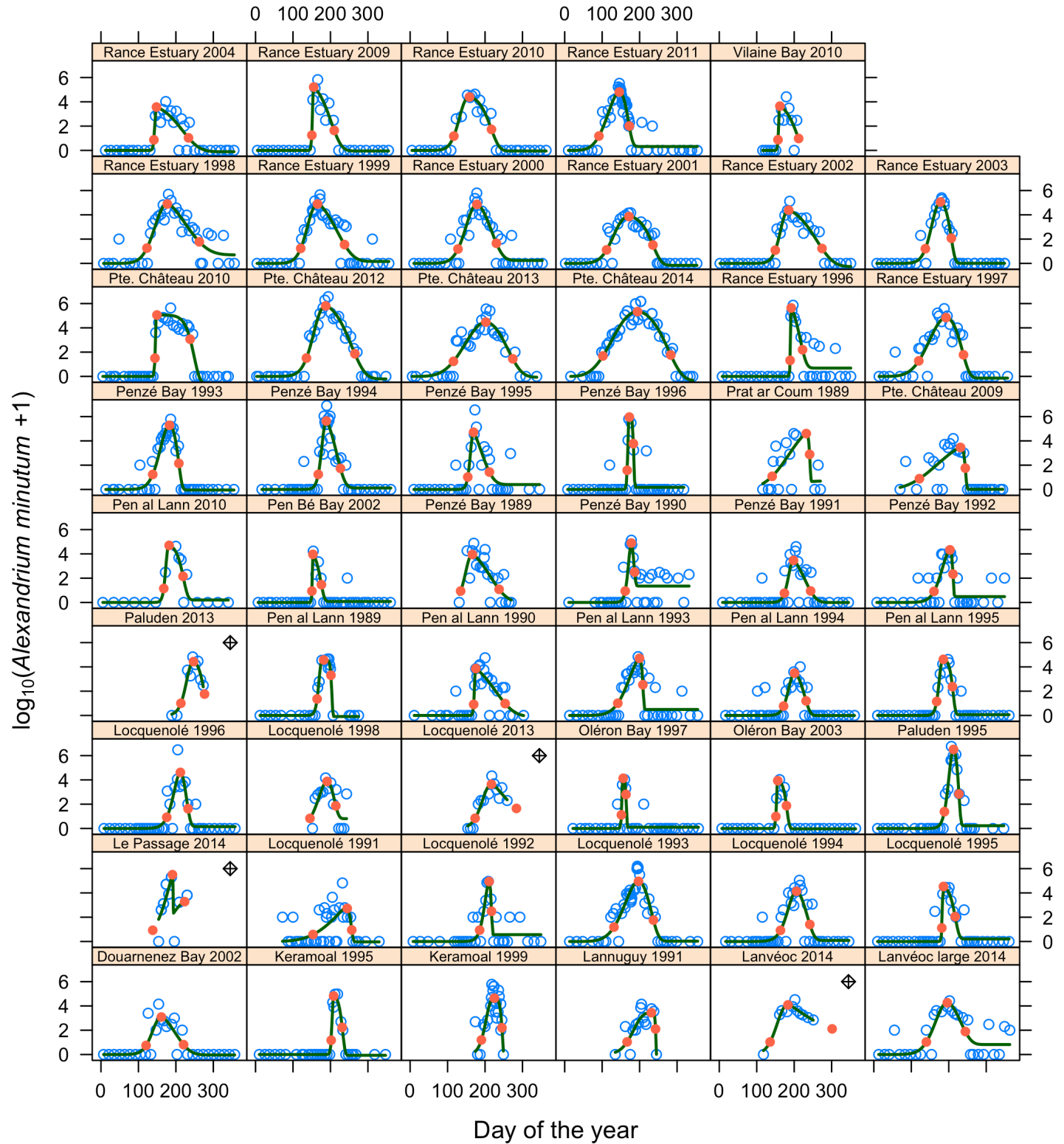


Supplementary figure 2. Relationship between phenology parameters: (A) Steepness Increase (SI, bullets) or inverse of SI (circles) vs. Increasing Length (IL), (B) Steepness Decrease (SD, bullets) or inverse of SD (circles) vs. Decreasing Length (DL).
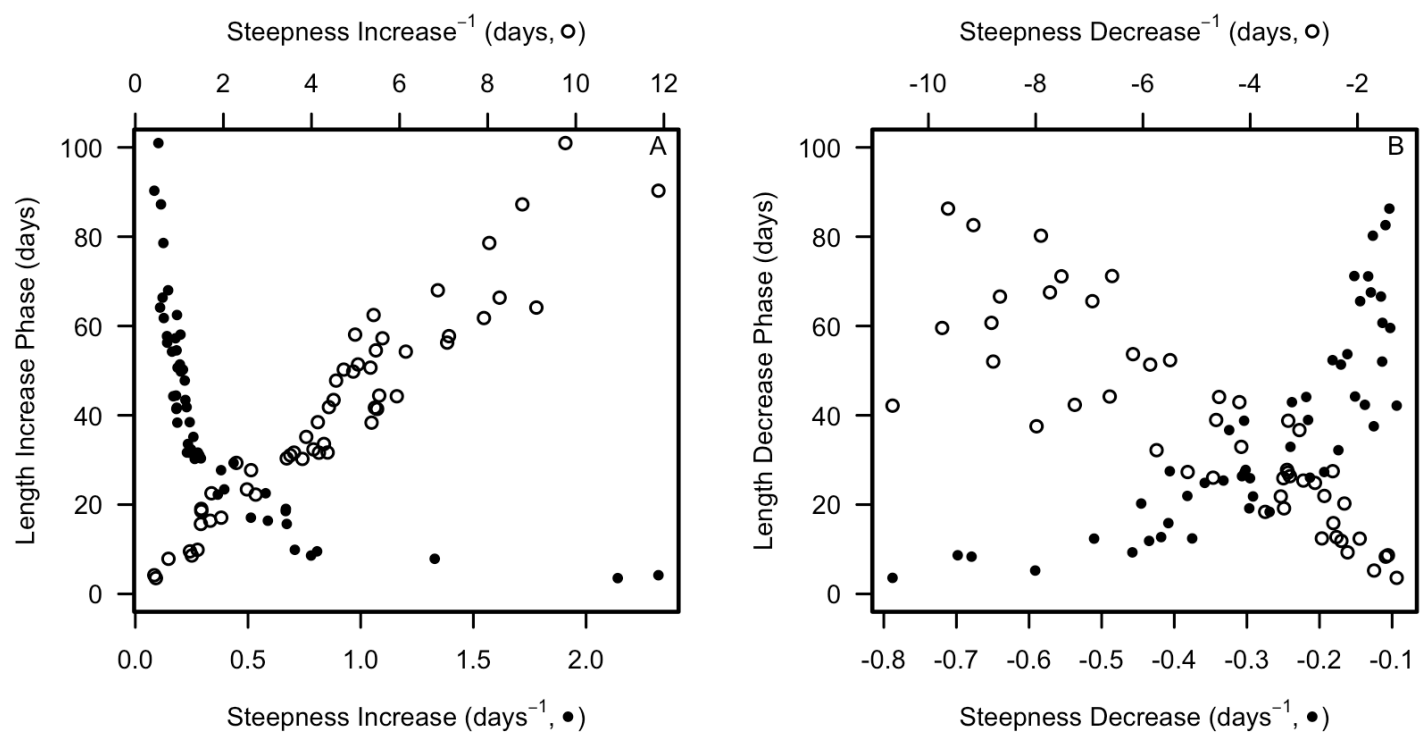

Supplementary figure 3. Scatterplot between mean water column temperature of the decreasing phase and (A) the length of the decreasing phase or (B) the steepness of the decreasing phase. The outlier corresponds to the TS of Oléron in 2003 in which a sustained strong wind abruptly stops the bloom.

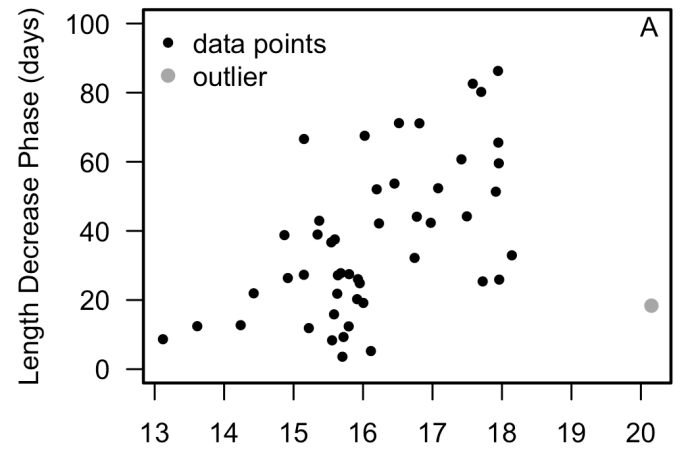

Decreasing phase mean water Temp. $\left({ }^{\circ} \mathrm{C}\right)$

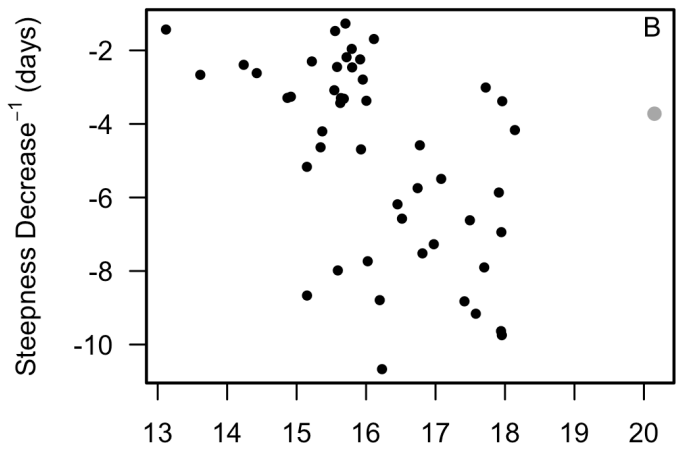

Decreasing phase mean water Temp. $\left({ }^{\circ} \mathrm{C}\right)$ 
Supplementary figure 4. Threshold analysis performed with all available data for (A) salinity, (B) irradiance, (C) wind velocity and (D) pressure, not used in this study.

Salinity and irradiance analysis apparently showed no marked influence in the abundance data in the studied range. Wind velocity was discarded because this variable is site-dependent and there is no sense to use global threshold values. In addition, no significant results were obtained for regional threshold analysis for this variable.

Pressure threshold values were discarded because this variable is a proxy of weather conditions, already analysed.
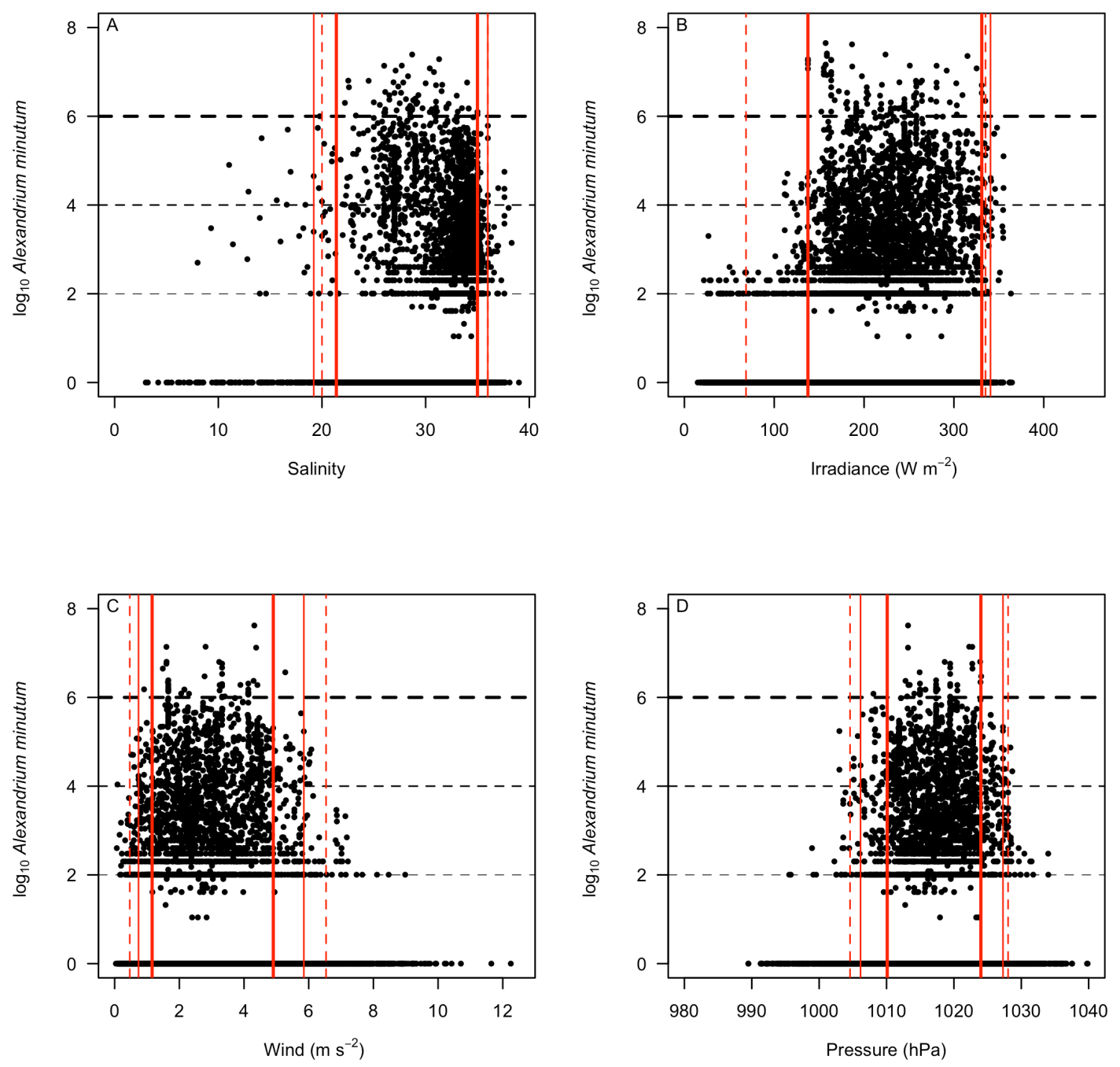
Supplementary figure 5. Threshold values for (A) Phosphate and (B) Nitrate plus Nitrite for the Penzé Bay.
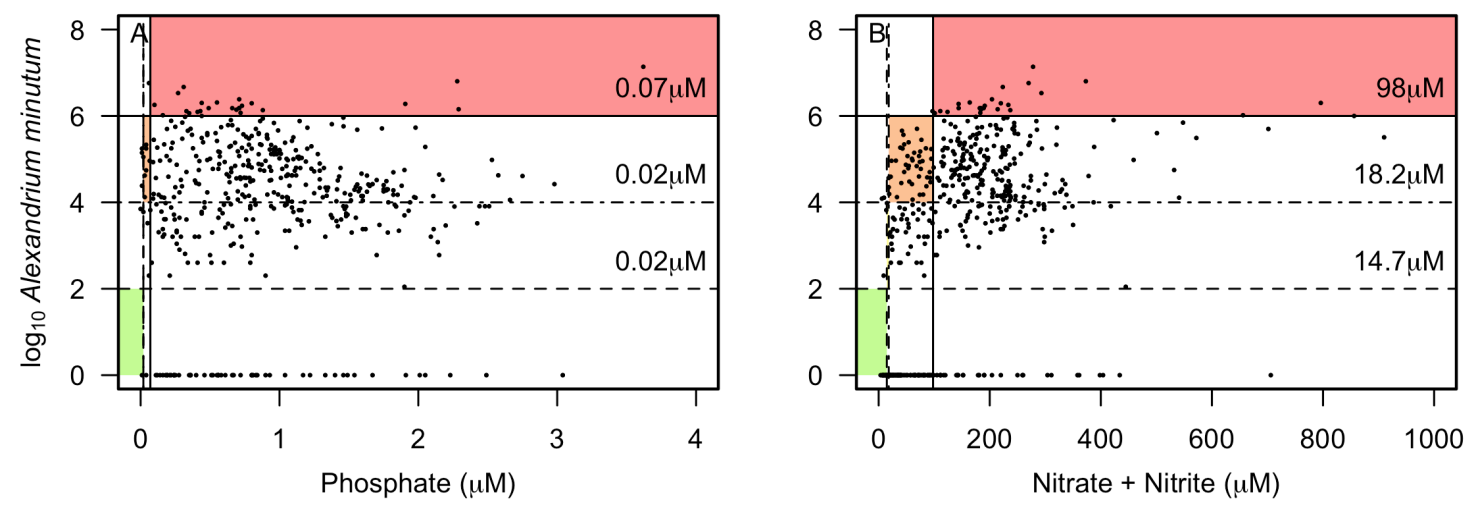
Supplementary figure 6. Representation of bloom, environmental variables evolution, phenology parameters and threshold analysis in (A) 1990, (B) 1991, (C) 1993, (D) 1994 and (E) 1995 at Penzé Bay. Colour scale represents environmental variables threshold values, grey scale represents environmental variable intensity and shaded rectangles represent PSP toxicity levels.

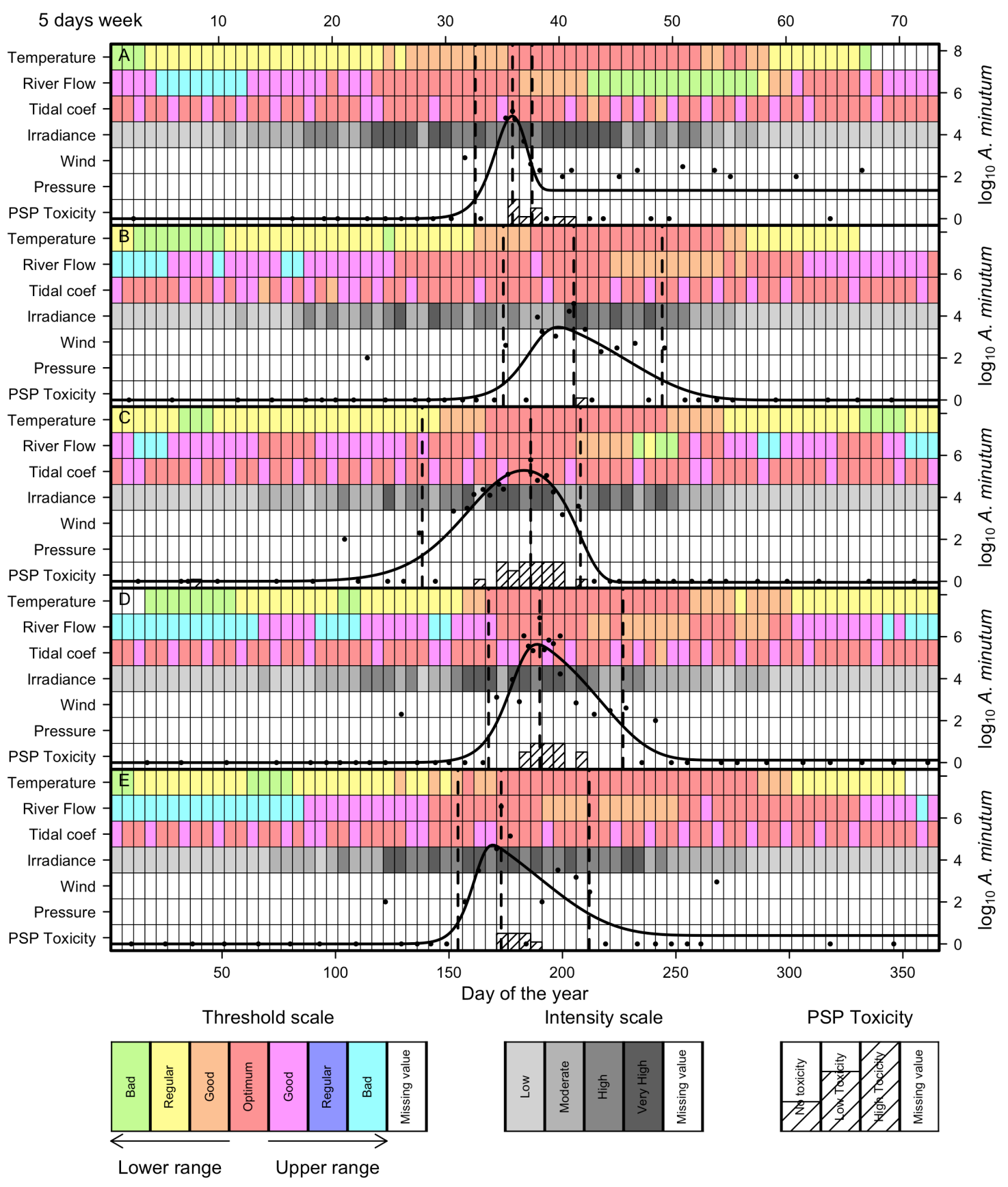


Supplementary figure 7. Representation of bloom, environmental variables evolution, phenology parameters and threshold analysis in (A) 2012, (B) 2013 and (C) 2014 at Pointe du Château (Brest Bay). Colour scale represents environmental variables threshold values, grey scale represents environmental variable intensity and shaded rectangles represent PSP toxicity levels.

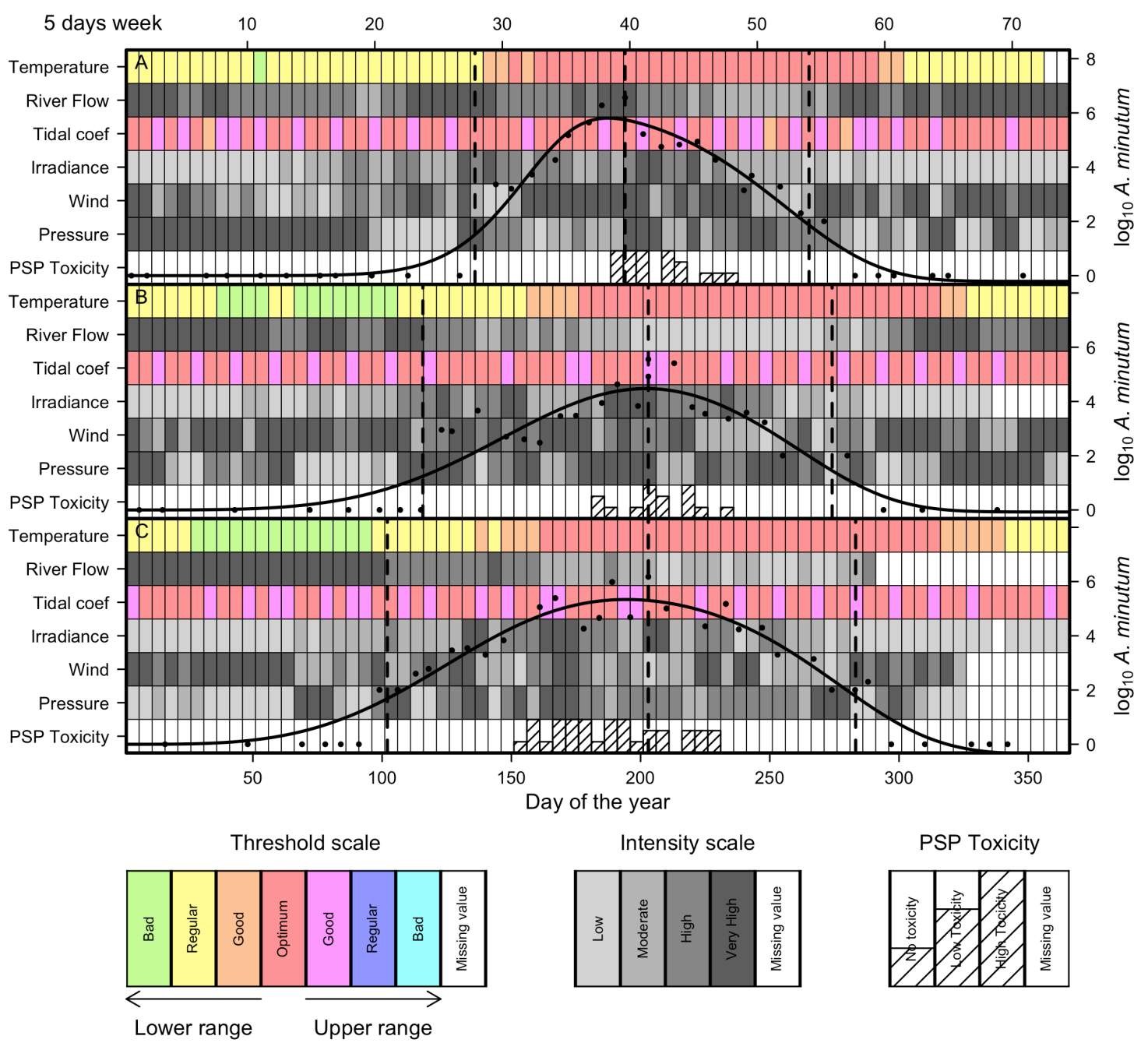


Supplementary figure 8. Maximum abundance per year for the regions studied. Each region includes the maximum abundance per year from the primary data set and from each TS studied. Triangles and circles correspond to years included and non-included in the phenology analysis, respectively. White, light grey, dark grey and black fillings represent TS without toxicity data, no toxicity $(<400 \mu \mathrm{g}$ saxitoxin equivalents $/ \mathrm{kg}$ shellfish), low toxicity ( $\geq 400 \mu \mathrm{g}$ saxitoxin equivalents/kg shellfish) and high toxicity ( $\geq 800 \mu \mathrm{g}$ saxitoxin equivalents/kg shellfish), respectively.

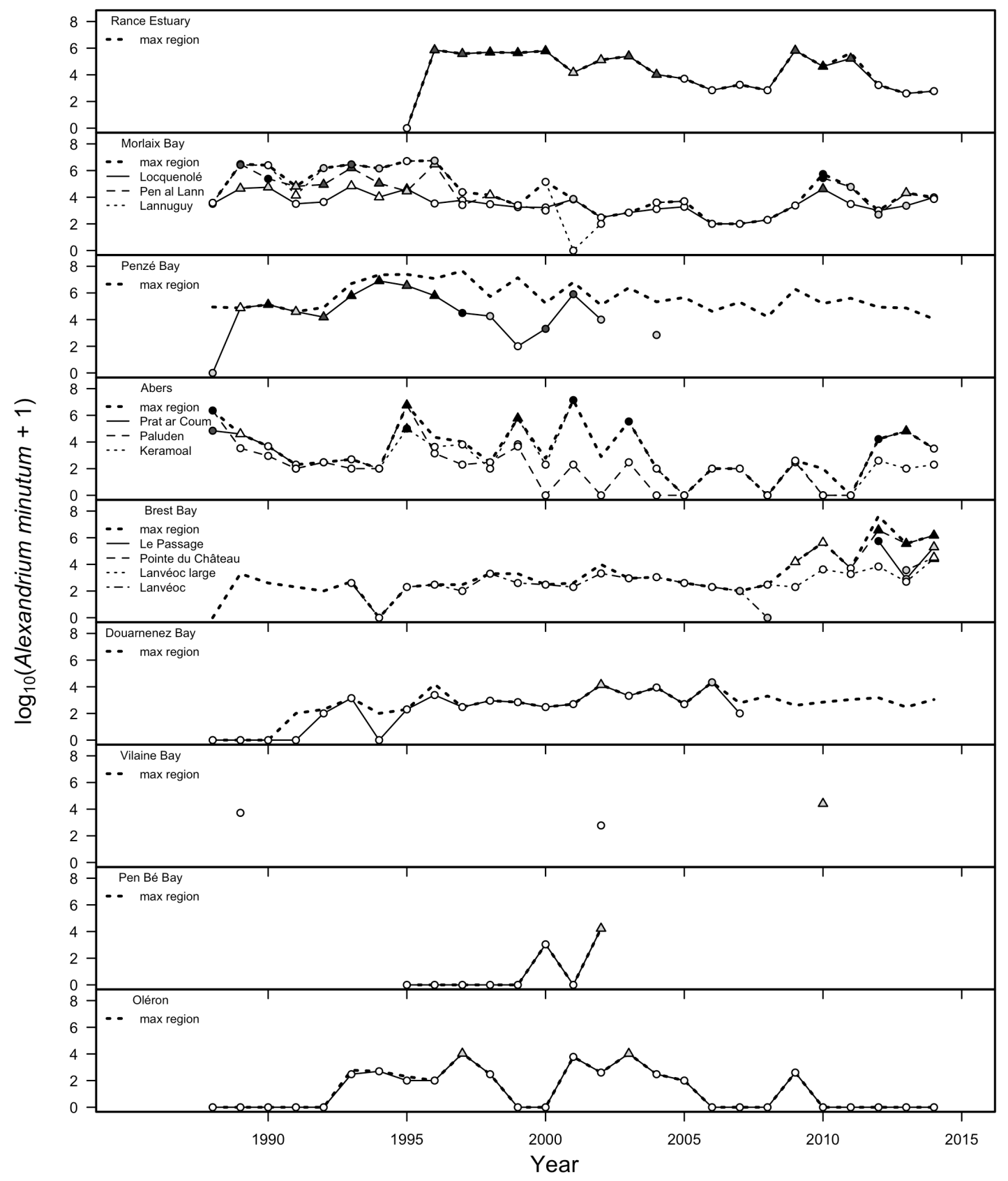


Supplementary figure 9. Representation of bloom, environmental variables evolution, phenology parameters and threshold analysis in 2003 at Oléron. Colour scale represents environmental variables threshold values, grey scale represents environmental variables intensity and shaded rectangles represent PSP toxicity levels. In 5days-week number 37 a period of strong winds coincide with the end of the bloom.

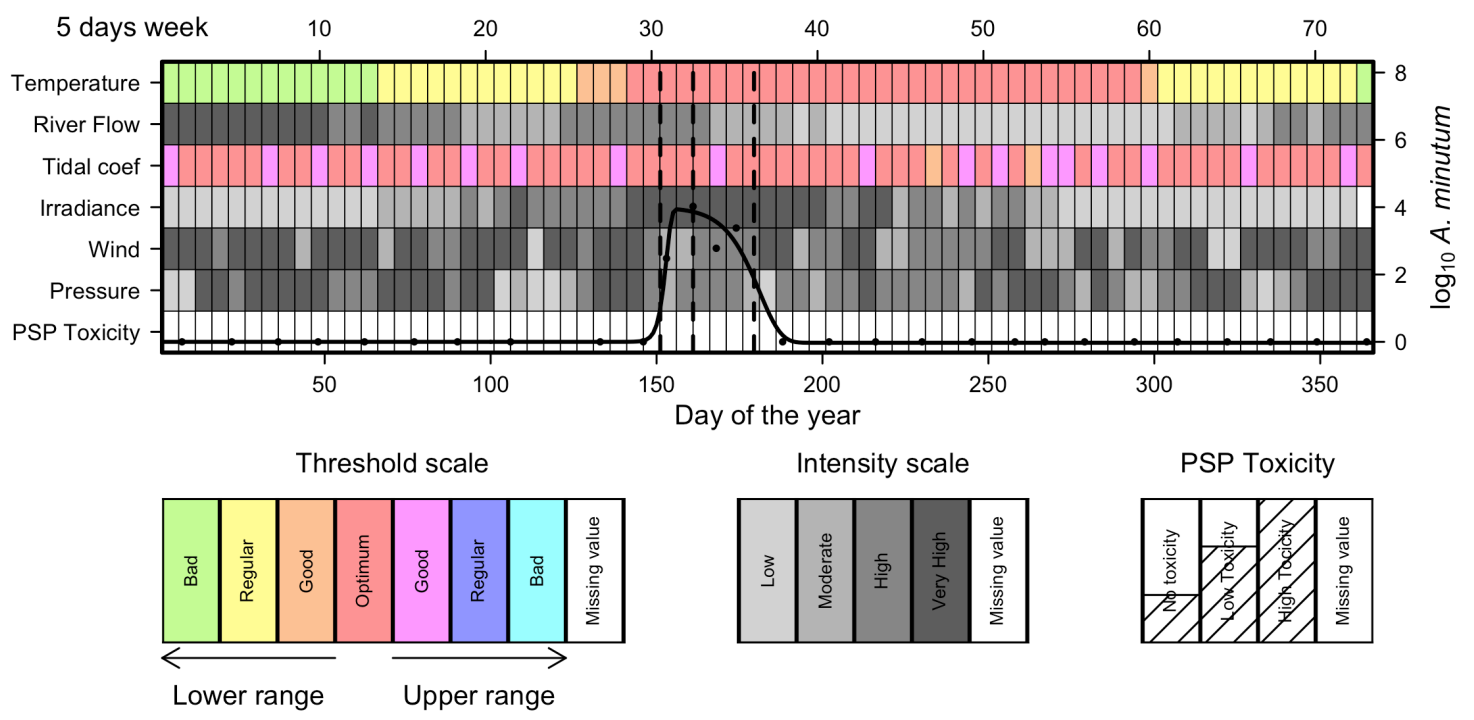

